\title{
Electrical Resistivity Tomography as a Support Tool to Estimate Physicochemical Properties of Mining Tailings Pond
}

\author{
María Gabarrón', Pedro Martínez-Pagán²*, Marcos A. Martínez-Segura², Silvia Martínez- \\ Martínez $^{1}$, Angel Faz ${ }^{1}$, Jose A. Acosta ${ }^{1}$ \\ 1 Sustainable Use, Management and Reclamation of Soil and Water Research Group. ETSIA. Universidad \\ Politécnica de Cartagena. Paseo Alfonso XIII, 52, 30230 Cartagena, Spain; maria.gabarron@upct.es \\ 2 Department of mine and civil engineering. Universidad Politécnica de Cartagena. Paseo Alfonso XIII, 52, \\ 30230 Cartagena, Spain; p.martinez@upct.es \\ * Correspondence: p.martinez@upct.es; Tel.: 0034676349301
}

\begin{abstract}
Legacy mining industry has left a large number of tailings ponds exposed to water and wind erosion that causes serious environmental and health problems. Prior to rehabilitation actions a deep sampling of the materials infilling the pond used to be necessary. Thus, the primary objective of this study is to demonstrate the usefulness of the Electrical Resistivity Tomography (ERT) method as a non-invasive tool to determine the physicochemical composition of mine tailings ponds, enabling more efficient and low-cost surveys. To achieve this objective, three ERT profiles and three boreholes in each profile were carried out, from each borehole three waste samples from differents depths were collected and a geochemical characterization of the samples was carried. In order to estimate the composition of the infilling wastes in tailing ponds from electrical resistivity measures, several regression models were calculated for different physicochemical properties and metal concentrations. As a result, a high resistivity area was depicted in profiles G2 and G3 while a nonresistive area (profile G1) was also found. Relationships among low resistivity values and high salinity, clay content and high metal concentrations and mobility were established. Specifically, calibrated models were obtained for electrical conductivity, particles sizes of 0.02-50 $\mu \mathrm{m}$ and 50$2000 \mu \mathrm{m}$, total $\mathrm{Zn}$ and $\mathrm{Cd}$ concentration, and bioavailable Ni, Cd and Fe. Therefore, the ERT technique could be considered as a useful tool for mine tailings ponds characterization, and it can be used to estmate some physicochemical properties and metal concentrations of this mine waste.
\end{abstract}

Keywords: ERT method; regression model; tailings pond; heavy metal; reclamation

\section{Introduction}

The mining of metalliferous mineral deposits and associated smelting and metal processing activities has lead to perturbations in the surface environment [1]. Indeed, metal-based ore processing generates large amount of mine tailings, which are watery sludge composed of medium-to finegrained material [2]. Due to natural leaching from these reactive materials, contamination of the environment close to the deposits often occurs [3]. In the Cartagena-La Union mining district (SE Spain) the legacy of more than 2500 years of intensive mining activity has left a large number of tailings ponds with considerable environmental impacts by generating leachates with high contents of sulphides and certain metallic elements [1,4-7] due to their wastes are characterized by significant content in metals such as $\mathrm{Pb}, \mathrm{Zn}, \mathrm{Cu}$, and $\mathrm{Cd}$, high salinity, acidic $\mathrm{pH}$ levels and low soil organic matter content [8]. Moreover, on the mining ponds it makes the natural establishment of vegetation difficult. In fact, tailings ponds are waste storage structures with bare surfaces completely exposed to erosion agents which promote the transport of those contaminants to the surrounding areas [9]. It 
has been demonstrated that plant cover provides physical protection to minimize wind erosion and surface runoff of soil materials [10].

To appropriately implement the application of phytostabilization techniques, it is required a precise and representative physicochemical characterization of the tailing ponds, for which it would be needed to collect representative samples from the tailing ponds not only from the surface but also from inside by means of core sampling acquisition tools or mechanical drilling rigs [6]. However, to accomplish this adequate physicochemical characterization through conventional sampling techniques such as boreholes, auger drilling, superficial sampling grids, etc., it is required an high budget and work time-consuming [11,12]. Therefore, it would be interesting to minimize those drawbacks with the assistance of geophysical techniques, especially the electrical resistivity tomography (ERT) method as over the last years, there have been revolutionary improvement to the resistivity method where two-dimensional (2-D) surveys are now routinely conducted in many study fields [13].

The electrical resistivity method is one of the oldest and most commonly used geophysical exploration methods [14]. Indeed, electrical resistivity tomography method is a non-invasive technique that enables to obtain a large number of resistivity data in a short period of time which has been widely used in environmental and engineering [15-19], hydrological [20,21], archaeological $[22,23]$ and mineral exploration [24-26] surveys. In addition, it has been used to image structures from the millimetre scale to kilometres [27,28].

Most of the studies carried out on tailings ponds using the electrical resistivity tomography method have been focused on identifying the tailings internal structure, defining the morphology of the tailings-bedrock contact, highlighting the occurrence of faults or cracks that could put at risk the whole pond stability and/or pinpointing preferential pathways for heavy metal transport or acid mine drainage $[6,7,11,12,29,30]$. However, studies on tailings ponds mainly focused on employing ERT method to establish relationships among electrical resistivity data and physicochemical variables such as moisture, heavy-metals content, $\mathrm{pH}$ values, particle size distribution, etc., are really scarce [6].

In this study, we attempt to establish relationships between the physicochemical properties of the tailing and electrical resistivity data. We hypothesize stablish regression models to predict the composition of the waste based on these relationships, avoiding huge sampling campaigns. Regression models based on electrical resistivity data has been widely used to estimate water flows and soil moisture content, usually in crop soils [19,31-34]. However, the use of regression models to estimate soil properties and metal concentrations using the electrical resistivity as reference variable is quite new $[19,34,35]$.

Therefore, the primary objective of this paper is to demonstrate the usefulness of ERT as a noninvasive method to determine the physicochemical composition of mine tailing ponds, thus enabling more efficient actions of environmental protection.

\section{Material and methods}

\subsection{Study area}

Cartagena-La Union mining district is located in the southeast of the Murcia Province (Spain) (Figure 1). Considered one of the most ancient mining areas of Europe, developed an important industrial activity since Romans to the first half of the 20th century that caused landscape and environmental damages in the area, especially due to the accumulation of mine wastes in ponds and acid mine drainages. 


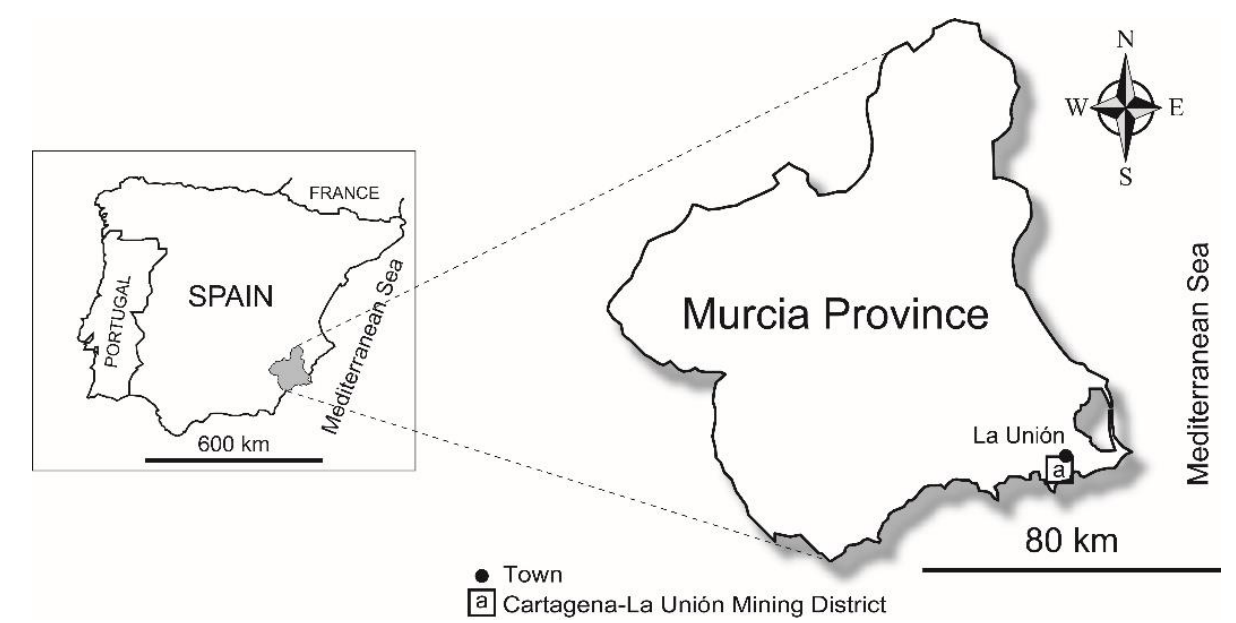

Figure 1. Location of the study area

The climate of the area is semiarid Mediterranean, characterized by an annual average temperature of $18^{\circ} \mathrm{C}$ and an annual precipitation of $290 \mathrm{~mm}$ [36]. This study is focused on a tailing pond $\left(37^{\circ} 35^{\prime} \mathrm{N}, 0^{\circ} 52^{\prime} \mathrm{W}\right)$ that presents an area of $7400 \mathrm{~m}^{2}, 14 \mathrm{~m}$ of depth and $150000 \mathrm{~m}^{3}$ of volume [4]. It was considered representative for their characteristics of salinity, lack of vegetation, metal content, low organic matter and affection by water and wind erosion [4]. In September 2011, a remediation project was carried out, amending the mining wastes with marble sludge and pig slurry (European Commission Framework Project FP7 IRIS) [37].

The studied tailings pond, like other tailings ponds in this mining district, was formed as a result of the disposal of mine waste generated from mineral processing of $\mathrm{Cu}-, \mathrm{Pb}$ - and $\mathrm{Zn}$-based Sulphur ores. Ponds were formed by gravitational accumulation of waste materials discharged from wooden sluices with multiple outlets (Figure 2a). Water in the tailings was drained through either a decant outlet situated in the center or drainage pipes installed on the perimeter of the pond. Due to gravity, the configuration of the ponds led to the settling of heavy and coarse particles close to the dam, while light and fine materials were concentrated near the water disposal points. As in many mined areas in the world, when a tailing pond was full, another dam was constructed upstream leading to a series of dams (Figure 2b) [38]. 


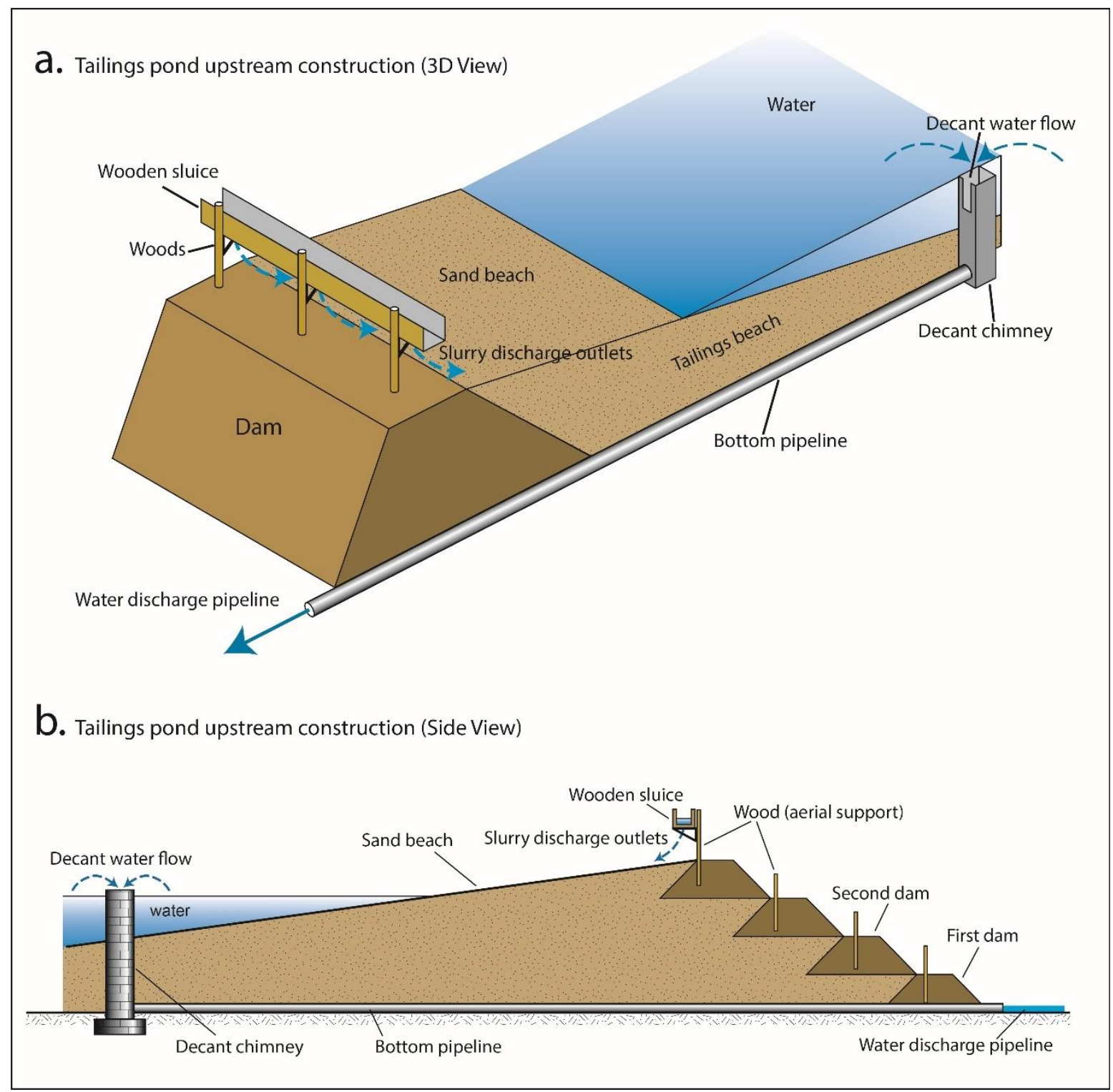

Figure 2. Tailings pond construction a) 3D view, b) side view.

\subsection{Electrical resistivity tomography (ERT) method}

The electrical resistivity tomography (ERT) method was employed as a primary geophysical technique. This geophysical technique is suitable to investigate complex subsurface structures with vertical and lateral resistivity changes [18\}, where those resistivity values are influenced by the variation of some important properties of the ground such as moisture, soil salinization, heavy metals content, particle size distribution, etc. [39].

Three small ERT profiles were laid out on the tailing pond to characterize accurately the tailings pond surface (Figure 3). It should be noted that the position and orientation of those ERT profiles were chosen according to electrical data previously obtained as part of the European Commission Framework Project [37]. 

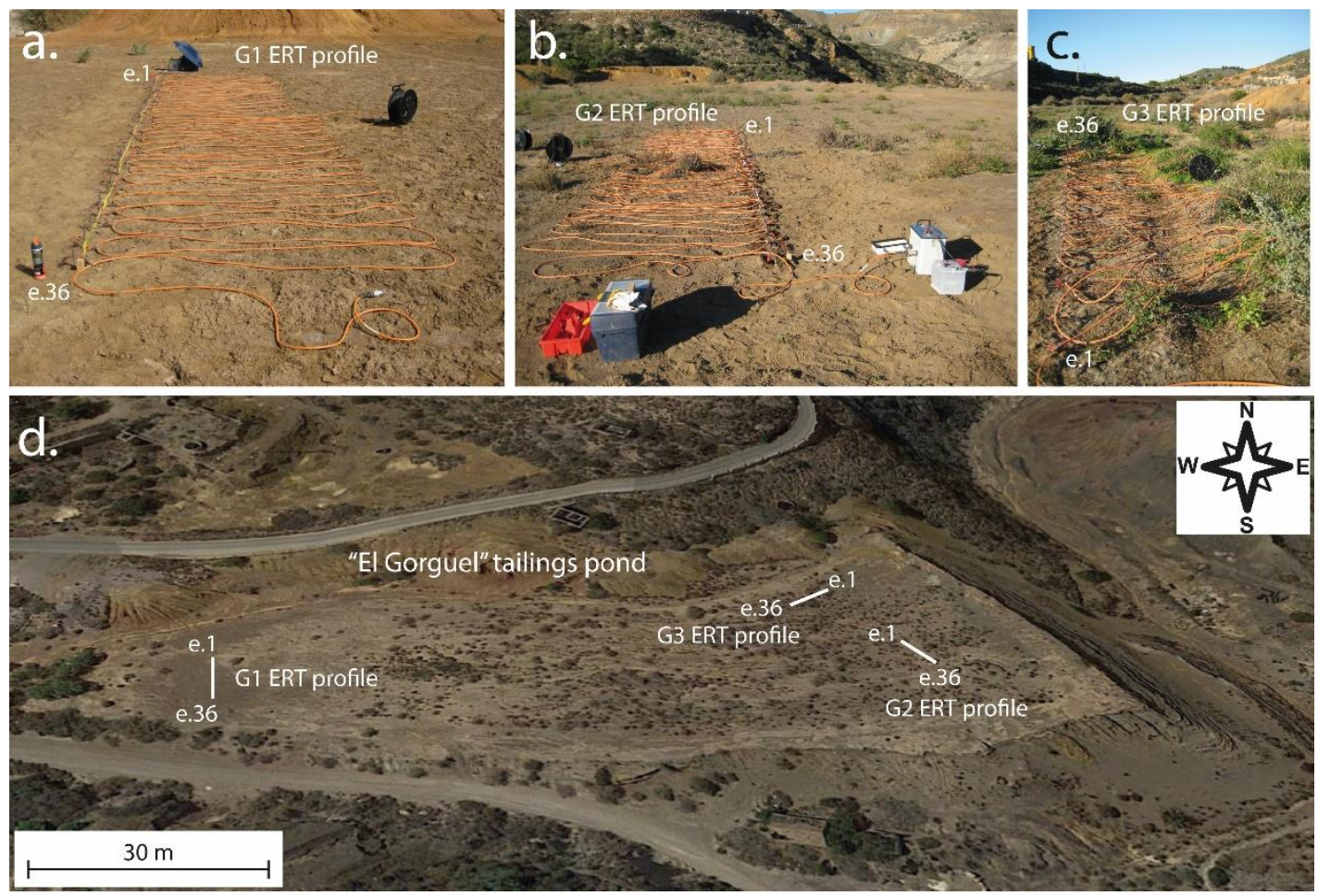

Figure 3. Detailed view of ERT Profile G1(a), G2 (b) and G3 (c) and the location of the profiles into de the tailing pond $(\mathrm{d})$

Apparent resistivity measurements were obtained by a Syscal R1 resistivity-meter (IRIS Instruments) with 36 stainless steel electrodes laid out in a transect at constant intervals with $30 \mathrm{~cm}$ electrode spacing and a total length of $10.8 \mathrm{~m}$. In order to combine a good penetration depth, a reasonable vertical and horizontal resolution, the dipole-dipole array was chosen for this study [40,41]. This measurement array has been successfully used in similar studies [17]. It is noted that a depth of investigation of $2 \mathrm{~m}$ was previously programmed through the ELECTRE II software [42].

Then, the apparent resistivity data sets from each ERT profile were processed following two stages: 1) Initial filtering and removing of the noisy data by means of PROSYS II software; 2) Data processing through RES2DINV software [43] for 2D ERT mathematical inversion based on matching iterations [44] where measured resistivity data are compared with those calculated by the software in order to get a 2D electrical section [45]. The 2D electrical section comprises a distribution of actual electrical resistivity data which are related to the variation of the physicochemical characteristics of the tailings pond [46].

\subsection{Sampling collection and geochemical analysis}

Twelve soil samples were collected from each ERT profile (G1, G2, G3) at 0-30 cm, 30-60 cm and $60-90 \mathrm{~cm}$ depth using a manual core and packed in plastic bags to be carried to the laboratory.

Samples were dried in a forced-air oven at $45^{\circ} \mathrm{C}$ for $72 \mathrm{~h}$ and sieved through a $2 \mathrm{~mm}$ mesh for physicochemical analysis. A piece of sieved sample was ground with an agate mortar (RetschRM 100). 
$\mathrm{pH}$ was measured in a solution of 1:2.5 soil/water ratio [47] and electrical conductivity (EC) was measured in a 1:5 soil/water suspension [47]. Organic carbon was determined by the dichromate method [47] and calcium carbonate was determined by the volumetric method of Bernard's calcimeter. Particle size analysis was carried using the Bouyoucos method [48].

Pseudo-total metal concentration was determined by acid digestion of $1 \mathrm{~g}$ of ground sample adding $10 \mathrm{ml} \mathrm{HNO}_{3}$ and $10 \mathrm{ml} \mathrm{H}_{3} \mathrm{ClO}_{4}$ heated at $210^{\circ} \mathrm{C}$ for 90 minutes in a heating-block equipped with temperature sensor and time control panel to ensure the digestion. To minimize the loss by evaporation or volatilization, a recovery system for gases was used in the procedure. After cooling, the samples were passed through a $0.2 \mu \mathrm{m}$ filter for quantitative analysis, and $0.1 \mathrm{~N} \mathrm{HCl}$ was added to volume in a $100 \mathrm{ml}$ volumetric flask [49]. The total amounts of metals $(\mathrm{Zn}, \mathrm{Pb}, \mathrm{Cu}, \mathrm{Cd}, \mathrm{Cr}, \mathrm{Ni}, \mathrm{Fe}$, As) were determined by ICP-OES/MS (Agilent 7500CE).

Bioavailable metals were measured using the Lindsay and Norvell (1978)[50] and Crock and Severson, (1980) [51] method, adding DTPA in a 1:2 soil /DTPA ratio. After shaking, samples were filtered and measured ICP-OES/MS (Agilent 7500CE). Water soluble metals were measured according to Buurman et al. (1996) [52] and Frau (2000) [53] method based in a 1:5 soil/water ratio. After shaking and filtering, extracts were measured by ICP-OES/MS (Agilent 7500CE). For quality assurance, reagent blanks, as well as certified reference materials (BAM-U110), available from the Federal Institute for Materials Research and Testing Research and Testing, were also run with the samples. Recoveries obtained for BAM-U110 were: $87 \%$ for $\mathrm{Pb}$; $95 \%$ for $\mathrm{Cu}$; $95 \%$ for $\mathrm{Ni}$; $86 \%$ for $\mathrm{Cr}$; $89 \%$ for $\mathrm{Zn} ; 97 \%$ for $\mathrm{Cd}$ and $81 \%$ for As.

\subsection{Statistical analysis}

The Kolmogorov-Smirnov normality test at $\mathrm{P}<0.05$ was used to ensure a normality fitting of the data. No normal distribution of data was achieved even after log-transformation. As a consequence, the Mann-Whitney $U$ test at $\mathrm{P}<0.05$ was performed to assess significant differences among profiles for each variable. Spearman correlation was carried out to establish relationships between electrical resistivity data and waste physicochemical properties. These statistical analyses were performed with the software IBM SPSS statistics v.23.

In this study, a simple nonlinear regression analysis was carried out to obtain a model that allowed the prediction of waste properties and metal content in amended tailings ponds based on electrical resistivity data. The selected-response variable $(\mathrm{Y})$ was the different waste properties or metal concentration, while the waste resistivity was used as an explanatory variable for prediction (X). Boxplot graphs were used to determine outlier data that were excluded from the test. The $75 \%$ of the total data was used as a calibration set, while the remaining $25 \%$ of the total data was used as a validation set. Residuals from the calibrated models were satisfactory checked for the model assumptions of normality (Kolmogorov-Smirnov test), linearity and homoscedasticity, and equations with $\mathrm{R}^{2}<0.6$ were rejected. To validate the models, residuals from the estimated variables of the validation set should be within the confidence interval (CI) (at 95\%) of the residual distribution of the calibrated model. CI was calculated as \pm 1.96 -standard deviation of the residuals in the calibrated model. Modelling was performed with the software SigmaPlot v.12 (Systat Software, Inc.). 


\section{Results and discussion}

\subsection{Soil properties, metal concentration and ERT imaging}

$\mathrm{pH}$ in the tailing pond ranged from slightly acid to moderately alkaline [47]. This was due to the fact that in the previous rehabilitation project, experimental plots were built and marble waste (98\% carbonates) was not applied to the whole pond surface [37]. Salinity (EC) ranges from very slightly saline to slightly saline [47] due to the coprecipitation of metallic salts with carbonates from the amendments [54]. Inorganic carbon, organic carbon and nitrogen showed low contents (Table 1) as were expected in these mining wastes. Particle size distribution in the tailing pond was dominated by coarse-size $(50-2000 \mu \mathrm{m})$ and medium-size $(0.02-50 \mu \mathrm{m})$ particles.

All metal analysed exceeded the limit established as reference of non-polluted soils (NGR) in the Region of Murcia [55], except $\mathrm{Cr}$ and $\mathrm{Ni}$ that showed values close to the background level of the area. Therefore, total $\mathrm{Zn}$ concentration (mean of the whole pond $8263 \mathrm{mg} \mathrm{kg}^{-1}$ ) was 92-time higher than the NGR (90 $\left.\mathrm{mg} \mathrm{kg}^{-1}\right)$, while Pb (3394 $\left.\mathrm{mg} \mathrm{kg}^{-1}\right)$ and Cd (123 $\left.\mathrm{mg} \mathrm{kg}^{-1}\right)$ showed values 60 and 50time higher than their reference values ( 57 and $0.5 \mathrm{mg} \mathrm{kg}^{-1}$, respectively); As (350 $\mathrm{mg} \mathrm{kg}^{-1}$ ), considered one of the most toxic elements for human health [56], exceeded 22-times the NGR (16 mg kg-1). Finally, $\mathrm{Cu}$ was 4-fold higher than its NGR (30 $\left.\mathrm{mg} \mathrm{kg}^{-1}\right)$. Similar concentrations of $\mathrm{Zn}, \mathrm{Pb}$ and $\mathrm{Cd}$ were found in tailings ponds from the Cartagena-La Unión mining district $[11,57,58]$.

About the mobility of metals, the highest concentration of bioavailiable metals was showed by $\mathrm{Zn}$ and $\mathrm{Pb}$, although the ratio between the mean bioavailable concentration and the mean total metal concentration revelaed that the most available metal was $\mathrm{Cd}$ followed by $\mathrm{Zn}, \mathrm{Pb}, \mathrm{Cu}, \mathrm{Ni}, \mathrm{Cr}$ and As. The water-solubility of metals was closed to zero, except $\mathrm{Zn}$ and $\mathrm{Cd}$ which showed little higher concentrations in some profiles.

The ERT survey showed big differences among the ERT profile G1 and profiles G2 and G3 (Figure 4). In G1, the whole section showed very low resistivity values (1-4 $\Omega \mathrm{m})$, except in a small area located between 30 and $60 \mathrm{~cm}$ depth where resistivity increased until $10 \Omega \mathrm{m}$ (Figure 4a). Profiles G2 and G3 showed a more heterogeneous distribution of the resistivity that allowed to depict different areas within each profile. Resistivity values in the main part of the G2 ranged from 25 to 90 $\Omega \mathrm{m}$. However, a higher resistivity area (region 1) can be discerned from the surface until $50 \mathrm{~cm}$ depth $(>100 \Omega \mathrm{m})$ as well as a lower resistivity area $(10-20 \Omega \mathrm{m})$ in the right side of the profile (region 3) (Figure $4 b$ ).

In G3 the highest resistivity area is located between the surface and $30 \mathrm{~cm}$ depth (region 1), showing values that reach the $90 \Omega \mathrm{m}$, which was quite in contrast with the low resistivity of the whole profile that ranges from 6 to $20 \Omega \mathrm{m}$ (Figure 4c). The presence of vegetation in G3 seems to be related with the lower resistivity in its surface compared with G2 as it is known that plant roots may alter the electrical resistivity of soils [59,60].

Similar resistivity values were obtained by Martín-Crespo et al. (2018)[12] from Brunita tailings pond (La Unión, Spain) and Acosta et al. (2017) [61] from tailings ponds in Mazarrón (Spain) mining district, where the same type of ores (pyrite, galena and sphalerite) were extracted. 
a.

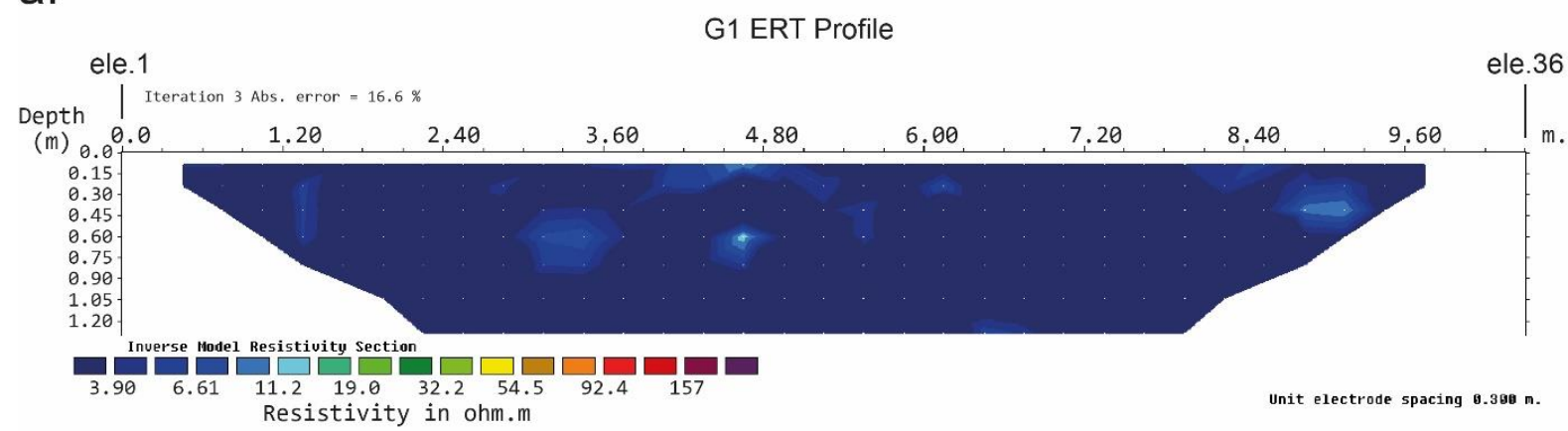

b.

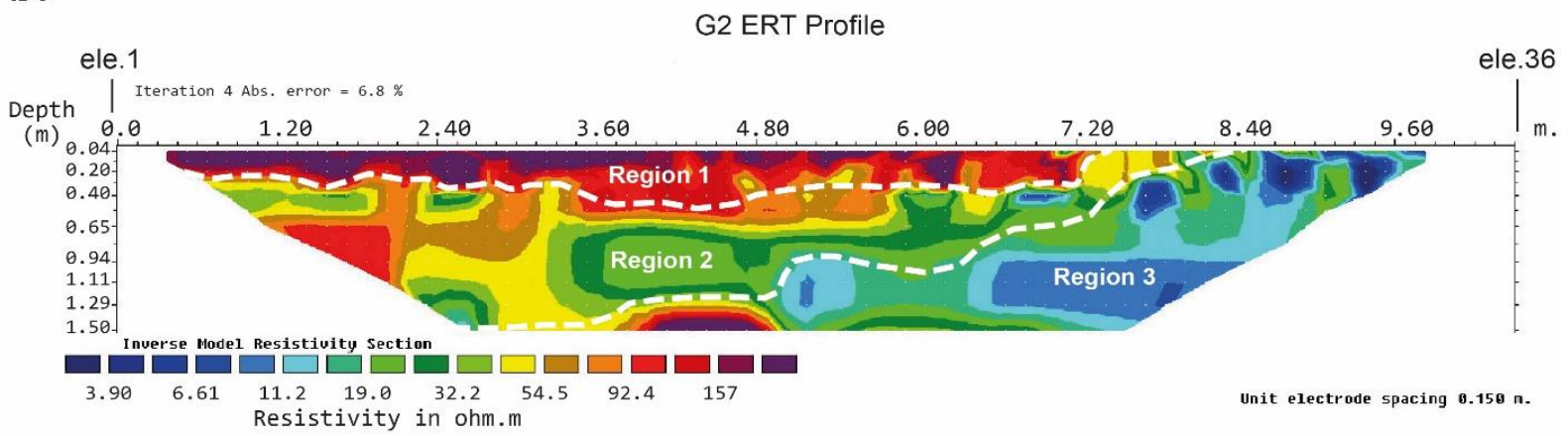

C.

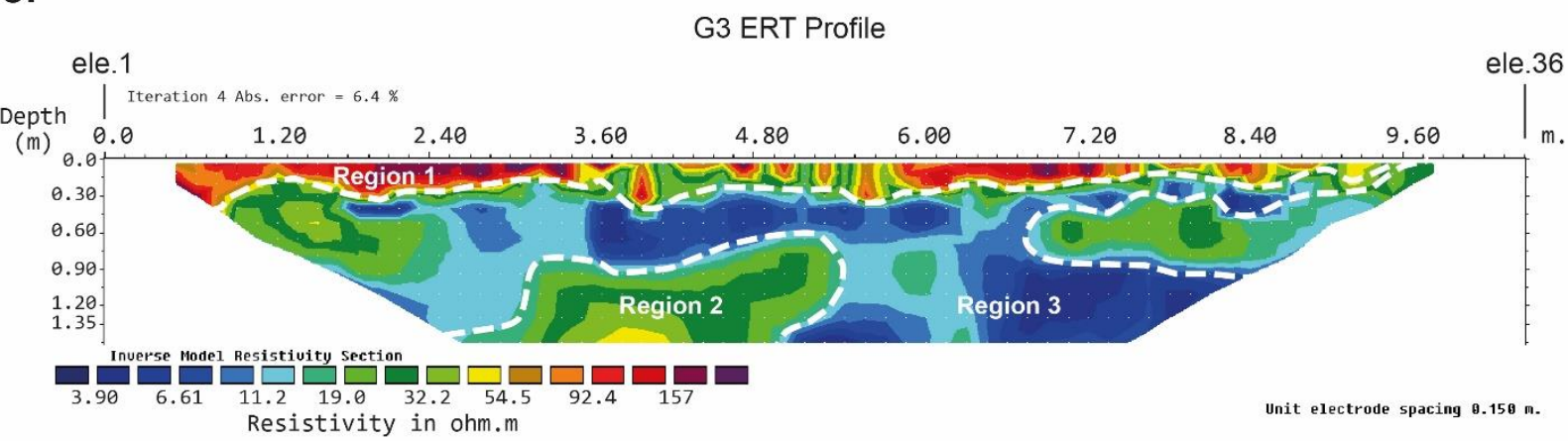

Figure 4. Electrical resistivity sections of Profiles G1 (a), G2 (b) and G3 (c)

Particle size distribution is closely related to electrical conductivity in soils, affecting the amount of surficial electrical charges of the solid soil constituents [43]. Hence, clayed size particles, characterized by the presence of connected pores, contributes to a better conduction of the electricity in soils, giving lower values of resistivity than sandy or loamy soils $[14,43,62,63]$. In the studied tailings pond, despite the coarse-size $(50-2000 \mu \mathrm{m})$ and medium-size $(0.02-50 \mu \mathrm{m})$ particles were predominant, statistically significant differences were found in G1, which showed a higher percentage of fine particles $(<0.02$ $\mu \mathrm{m}$ ) than G2 and G3 profiles (Table 1). Therefore, the lower resistivity values found in G1 seemed to be influenced by the higher presence of fine materials. This behaviour was in accordance with that found by Martín-Crespo et al. (2018)[12] and Faz et al. (2013)[64], who explains that in the CartagenaLa Unión mining district, materials that shows electrical resistivities below $8 \Omega \mathrm{m}$ correspond to finegrain tailings while resistivities ranging from 8 to $150 \Omega \mathrm{m}$ correspond to waste rocks. 
Table 1. Soil properties and metal concentration $\left(\mathrm{mg} \mathrm{kg}^{-1}\right)$

\begin{tabular}{|c|c|c|c|c|c|c|c|c|c|}
\hline & \multicolumn{3}{|c|}{ Profile G1 } & \multicolumn{3}{|c|}{ Profile G2 } & \multicolumn{3}{|c|}{ Profile G3 } \\
\hline & $0-30 \mathrm{~cm}$ & $30-60 \mathrm{~cm}$ & $60-90 \mathrm{~cm}$ & $0-30 \mathrm{~cm}$ & $30-60 \mathrm{~cm}$ & $60-90 \mathrm{~cm}$ & $0-30 \mathrm{~cm}$ & $30-60 \mathrm{~cm}$ & $60-90 \mathrm{~cm}$ \\
\hline Moisture (\%) & $17.21 \pm 2.15 \mathrm{a}$ & $22.21 \pm 2.15 a$ & $24.49 \pm 2.15 a$ & $4.87 \pm 0.08 \mathrm{~b}$ & $7.33 \pm 1.88 \mathrm{ab}$ & $6.32 \pm 1.17 \mathrm{~b}$ & $6.70 \pm 0.57 \mathrm{ab}$ & $7.61 \pm 0.84 \mathrm{ab}$ & $7.75 \pm 0.23 \mathrm{ab}$ \\
\hline $\mathrm{pH}$ & $8.35 \pm 0.06 a$ & $7.03 \pm 0.06 \mathrm{c}$ & $7.94 \pm 0.06 c$ & $6.13 \pm 0.20 \mathrm{ab}$ & $8.13 \pm 0.23 \mathrm{ab}$ & $8.11 \pm 0.50 \mathrm{ab}$ & $8.33 \pm 0.23 \mathrm{abc}$ & $8.51 \pm 0.15 \mathrm{ab}$ & $8.14 \pm 0.13 \mathrm{abc}$ \\
\hline I.C (\%) & $0.46 \pm 0.04 c$ & $0.21 \pm 0.04 \mathrm{c}$ & $1.24 \pm 0.04 b c$ & $1.69 \pm 0.08 b$ & $1.96 \pm 0.35 \mathrm{ab}$ & $1.08 \pm 0.18 b c$ & $0.70 \pm 0.65 b c$ & $1.77 \pm 1.17 \mathrm{ab}$ & $0.60 \pm 0.22 b c$ \\
\hline OC (\%) & $1.14 \pm 0.07 \mathrm{a}$ & $0.28 \pm 0.07 \mathrm{~b}$ & $1.31 \pm 0.07 \mathrm{a}$ & $0.60 \pm 0.10 \mathrm{ab}$ & $0.64 \pm 0.23 \mathrm{ab}$ & $0.86 \pm 0.42 \mathrm{ab}$ & $1.17 \pm 0.13 a$ & $2.09 \pm 0.03 \mathrm{a}$ & $0.85 \pm 0.06 \mathrm{ab}$ \\
\hline $\mathrm{TN}(\%)$ & $0.01 \pm 0.00 \mathrm{a}$ & $0.02 \pm 0.00 \mathrm{~b}$ & $0.02 \pm 0.00 \mathrm{ab}$ & $0.01 \pm 0.00 \mathrm{ab}$ & $0.00 \pm 0.00 \mathrm{a}$ & $0.01 \pm 0.00 \mathrm{a}$ & $0.01 \pm 0.00 \mathrm{ab}$ & $0.01 \pm 0.00 \mathrm{ab}$ & $0.01 \pm 0.00 \mathrm{ab}$ \\
\hline $0.02-50 \mu \mathrm{m}$ & $21.87 \pm 2.04 \mathrm{a}$ & $30.36 \pm 2.04 a$ & $43.03 \pm 2.04 a$ & $12.13 \pm 5.86 \mathrm{a}$ & $14.45 \pm 3.07 a$ & $8.10 \pm 2.10 \mathrm{ab}$ & $8.04 \pm 3.57 \mathrm{ab}$ & $12.68 \pm 0.68 \mathrm{a}$ & $12.04 \pm 2.98 \mathrm{ab}$ \\
\hline $50-2000 \mu \mathrm{m}$ & $64.98 \pm 3.14 b$ & $59.18 \pm 3.14 b$ & $47.82 \pm 3.14 \mathrm{~b}$ & $59.13 \pm 1.16 \mathrm{ab}$ & $80.13 \pm 3.97 \mathrm{ab}$ & $84.84 \pm 2.31 \mathrm{a}$ & $81.38 \pm 3.08 a$ & $80.08 \pm 0.09 \mathrm{ab}$ & $79.37 \pm 3.02 \mathrm{ab}$ \\
\hline Total Zn & $11435 \pm 800 \mathrm{a}$ & $13695 \pm 800 \mathrm{a}$ & $12467 \pm 800 \mathrm{a}$ & $5817 \pm 406 b$ & $5645 \pm 924 b$ & $5388 \pm 299 b$ & $8138 \pm 2113 \mathrm{ab}$ & $5310 \pm 1481 \mathrm{ab}$ & $4528 \pm 935 b$ \\
\hline Total $\mathrm{Pb}$ & $4520 \pm 903 a$ & $5893 \pm 903 a$ & $5693 \pm 903 a$ & $2053 \pm 254 a b$ & $2989 \pm 168 \mathrm{ab}$ & $2329 \pm 108 \mathrm{ab}$ & $2797 \pm 163 \mathrm{ab}$ & $1712 \pm 785 b$ & $1867 \pm 433 b$ \\
\hline Total Cu & $151.85 \pm 6.44 a$ & $201.62 \pm 6.44 a$ & $208.26 \pm 6.44 a$ & $86.15 \pm 4.21 \mathrm{ab}$ & $100.45 \pm 3.72 \mathrm{ab}$ & $81.62 \pm 11.54 \mathrm{ab}$ & $94.80 \pm 29.09 \mathrm{ab}$ & $80.84 \pm 27.68 b$ & $68.41 \pm 10.95 b$ \\
\hline Total Cd & $37.15 \pm 3.77 \mathrm{a}$ & $33.93 \pm 3.77 a$ & $35.60 \pm 3.77 a$ & $20.45 \pm 1.40 \mathrm{ab}$ & $15.68 \pm 4.15 b$ & $15.73 \pm 1.03 \mathrm{~b}$ & $28.29 \pm 8.56 \mathrm{ab}$ & $16.73 \pm 3.11 \mathrm{~b}$ & $13.32 \pm 1.46 \mathrm{~b}$ \\
\hline 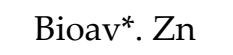 & $494.23 \pm 38.72 \mathrm{a}$ & $649.64 \pm 38.72 \mathrm{a}$ & $483.35 \pm 38.72 \mathrm{a}$ & $349.99 \pm 11.91 \mathrm{a}$ & $337.35 \pm 98.82 \mathrm{ab}$ & $241.38 \pm 85.79 b$ & $466.70 \pm 109.83 \mathrm{ab}$ & $266.23 \pm 61.40 \mathrm{~b}$ & $301.38 \pm 4.81 \mathrm{ab}$ \\
\hline Bioav. Pb & $88.24 \pm 58.35 b$ & $21.51 \pm 58.35 b$ & $93.48 \pm 58.35 b$ & $70.39 \pm 13.09 \mathrm{ab}$ & $149.46 \pm 12.22 \mathrm{ab}$ & $148.44 \pm 6.35 \mathrm{ab}$ & $116.48 \pm 65.02 \mathrm{ab}$ & $113.82 \pm 11.72 \mathrm{ab}$ & $162.10 \pm 9.60 \mathrm{a}$ \\
\hline Bioav. $\mathrm{Cu}$ & $5.53 \pm 0.75 a$ & $2.17 \pm 0.75 c$ & $6.87 \pm 0.75 \mathrm{ab}$ & $3.38 \pm 0.48 \mathrm{ab}$ & $4.37 \pm 0.46 \mathrm{ab}$ & $2.24 \pm 0.30 \mathrm{~b}$ & $4.15 \pm 0.83 \mathrm{ab}$ & $2.50 \pm 0.32 b c$ & $2.32 \pm 0.52 b c$ \\
\hline Bioav. Cd & $8.51 \pm 2.07 a$ & $7.49 \pm 2.07 a$ & $6.78 \pm 2.07 \mathrm{ab}$ & $1.81 \pm 0.35 \mathrm{bc}$ & $1.79 \pm 0.74 b$ & $1.58 \pm 0.68 b$ & $3.17 \pm 0.39 \mathrm{ab}$ & $2.20 \pm 0.19 b c$ & $2.61 \pm 0.35 b c$ \\
\hline Bioav. Cr & $<\mathrm{DL}$ & $<\mathrm{DL}$ & $<\mathrm{DL}$ & $<\mathrm{DL}$ & $<\mathrm{DL}$ & $<\mathrm{DL}$ & $<\mathrm{DL}$ & $<\mathrm{DL}$ & $<\mathrm{DL}$ \\
\hline Bioav. Ni & $0.32 \pm 0.07 a$ & $0.78 \pm 0.07 a$ & $0.44 \pm 0.07 a$ & $0.07 \pm 0.01 \mathrm{ab}$ & $0.08 \pm 0.01 \mathrm{ab}$ & $0.05 \pm 0.03 b$ & $0.08 \pm 0.03 \mathrm{ab}$ & $0.06 \pm 0.01 \mathrm{ab}$ & $0.07 \pm 0.01 \mathrm{ab}$ \\
\hline Bioav. Fe & $1.11 \pm 0.09 \mathrm{~b}$ & $0.95 \pm 0.09 b$ & $0.92 \pm 0.09 b$ & $6.22 \pm 0.47 \mathrm{ab}$ & $13.85 \pm 5.36 \mathrm{ab}$ & $35.89 \pm 2.15 a$ & $12.80 \pm 7.41 \mathrm{ab}$ & $21.97 \pm 1.85 a$ & $26.18 \pm 2.11 a$ \\
\hline Bioav. As & $0.02 \pm 0.01 \mathrm{a}$ & $0.01 \pm 0.01 \mathrm{a}$ & $0.02 \pm 0.01 \mathrm{a}$ & $0.01 \pm 0.00 \mathrm{a}$ & $0.01 \pm 0.00 \mathrm{a}$ & $0.02 \pm 0.00 \mathrm{a}$ & $0.01 \pm 0.01 \mathrm{a}$ & $0.01 \pm 0.00 \mathrm{a}$ & $0.01 \pm 0.01 \mathrm{a}$ \\
\hline Sol. ${ }^{*} \mathrm{Zn}$ & $2.72 \pm 1.13 a$ & $90.98 \pm 1.13 a$ & $1.45 \pm 1.13 a$ & $1.44 \pm 0.27 a$ & $2.61 \pm 0.59 a$ & $1.42 \pm 2.18 \mathrm{a}$ & $1.40 \pm 1.19 \mathrm{a}$ & $1.17 \pm 0.34 \mathrm{a}$ & $2.46 \pm 0.12 \mathrm{a}$ \\
\hline
\end{tabular}


10 of 20

\begin{tabular}{|c|c|c|c|c|c|c|c|c|c|}
\hline Sol. Pb & $0.05 \pm 0.02 \mathrm{a}$ & $1.62 \pm 0.02 \mathrm{a}$ & $0.09 \pm 0.02 a$ & $0.005 \pm 0.002 \mathrm{ab}$ & $0.003 \pm 0.004 \mathrm{ab}$ & $0.003 \pm 0.001 \mathrm{~b}$ & $0.004 \pm 0.006 \mathrm{ab}$ & $0.004 \pm 0.003 \mathrm{~b}$ & $0.004 \pm 0.001 \mathrm{~b}$ \\
\hline Sol. Cu & $0.001 \pm 0.001$ & $0.02 \pm 0.00$ & $0.02 \pm 0.00$ & $0.00 \pm 0.00$ & $<\mathrm{DL}$ & $<\mathrm{DL}$ & $<\mathrm{DL}$ & $<\mathrm{DL}$ & $<\mathrm{DL}$ \\
\hline Sol. Cr & $<\mathrm{DL}$ & $<\mathrm{DL}$ & $<\mathrm{DL}$ & $<\mathrm{DL}$ & $<\mathrm{DL}$ & $<\mathrm{DL}$ & $<\mathrm{DL}$ & $<\mathrm{DL}$ & $<\mathrm{DL}$ \\
\hline Sol. Fe & $0.18 \pm 0.06 \mathrm{a}$ & $0.76 \pm 0.06 a$ & $0.28 \pm 0.06 a$ & $0.16 \pm 0.05 a$ & $0.17 \pm 0.03 a$ & $0.16 \pm 0.03 a$ & $0.14 \pm 0.08 a$ & $0.16 \pm 0.04 a$ & $0.19 \pm 0.05 a$ \\
\hline Sol. As & $0.01 \pm 0.00 \mathrm{a}$ & $0.01 \pm 0.00 \mathrm{a}$ & $0.02 \pm 0.00 \mathrm{a}$ & $0.01 \pm 0.00 \mathrm{a}$ & $0.01 \pm 0.00 \mathrm{a}$ & $0.01 \pm 0.00 \mathrm{a}$ & $0.01 \pm 0.00 \mathrm{a}$ & $<\mathrm{DL}$ & $0.01 \pm 0.01 \mathrm{a}$ \\
\hline
\end{tabular}

*Bioav.: bioavailable. Sol.: water soluble. $<$ DL: lower than the detection limit of the equip. Different letters in the same raw means statistical differences between variables. 
No differences were found between G1 and G2-G3 for waste physicochemical properties except for salinity and inorganic carbon content which showed the highest contents in profile G1. In the studied pond, the inorganic carbon was mainly present in the form of calcium carbonate coming from the marble sludge used as amendment. Therefore, as the electrical resistivity values of marble sludge range from 100 to $180 \Omega \mathrm{m}$ [43], the highest values of resistivity observed in region 1 of G2 and G3 profiles could be related with the high resistivity of this material mixed with other minerals and metallic salts from the mining wastes.

Profile G3 at 30-90 cm depht showed a slightly higher content in organic carbon, total nitrogen and particles sizes of 0.02-2000 $\mu \mathrm{m}$ than G2, indicating a relation between the increase of these physicochemical properties and the lower electrical resistivity showed by G3 at 30-90 cm depth.

There were no significant variations in the soil properties with depth, except in G1 where $\mathrm{pH}$ decreases in depth.

Some minerals such as pyrite $\left(\mathrm{FeS}_{2}\right)$, sphalerite $(\mathrm{ZnS})$ or galena $(\mathrm{PbS})$ used to be poor conductors of electricity in their massive form but as individual crystals or combined with impurities can become very good conductors giving low resistivity values [14]. Also, the high specific surface of fine materials holds a high amount of water and metallic ions capable of conducting electricity. No statistical differences were found in the variation of total metal concentration with depth within G1, G2 and G3. However, a comparison between profiles showed statistical differences for total $\mathrm{Zn}$ content between G1 and G2, indicating a higher Zn concentration of G1 compared to G2. For total Pb and $\mathrm{Cu}$ were found statistical differences between G1 (0-90 cm depth) and G3 (30-90 cm depth), being higher the concentration of both metals in G1. Cd concentration in G1 (0-90 cm depth) showed also statistically different with Cd concentration in G2 and G3 at 30-90 cm depth, showing the highest values of total Cd in G1. Also, statistical differences were observed for total As between G1 $(0-30 \mathrm{~cm})$ and G2 $(0-30 \mathrm{~cm})$, although in this case the concrentration was higher in G2.

Highest concentrations of bioavailable metals were found in G1 where no statistical differences were found among sampling depths, except for $\mathrm{Cu}$ which bioavailable concentration decrease at 30-60 $\mathrm{cm}$ depth. By profiles, the availability of $\mathrm{Cd}$ decreases as $\mathrm{G} 1(21.4 \%)>\mathrm{G} 3(13.7 \%)>$ G2(9.8\%); for Zn as G3 (5.75\%) G2 (5.56\%)> G1 (4.33\%); for Pb as G3 (6.15\%)> G2 (4.86\%)> G1 (1.26\%) and for Cu G2 $(3.74 \%) \approx \mathrm{G} 3(3.67 \%)>\mathrm{G} 1(2.59)$. Ni, Cr and As showed bioavailable values close to zero for all profiles.

Water soluble metal concentrations were low for all metals except for $\mathrm{Zn}$ at 30-60 cm. Despite this fact, the $\mathrm{Cd}$ was the most soluble metal compared to the total Cd in G1 (4.7\%) while Zn just showed $0.25 \%$ of solubility at this profile.

The higher content of fine materials joined to the higher concentration and mobility of metals in G1 support the lower resistivity values found in this profile compared to profiles G2 and G3. A similar behaviour was observed in others tailings ponds from Cartagena-La Unión mining district (Spain)[64], Ursk (Russia) [65] or Viljakkala (Finland) [66].

\subsection{ERT model}


In order to identify linear and non-linear relationships among electrical resistivity and physicochemical parameters a Spearman correlation test was done. Results showed that resistivity was negative and significantly correlated with electrical conductivity $(R=-0.911 ; P<0.01)$, particles $<0.02 \mu \mathrm{m}(\mathrm{R}=-0.809 ; \mathrm{P}<0.01)$, moisture $(\mathrm{R}=-0.776 ; \mathrm{P}<0.01)$, bioavailable $\mathrm{Cd}(\mathrm{R}=-0.713, \mathrm{P}<0.01), \mathrm{TN}(\mathrm{R}=$ -0.696; $\mathrm{P}<0.001)$, soluble $\mathrm{Pb}(\mathrm{R}=-0.636, \mathrm{P}<0.01)$, soluble $\mathrm{Cd}(\mathrm{R}=-0.636 ; \mathrm{P}<0.01)$, bioavailable $\mathrm{Ni}(\mathrm{R}=-$ 0.6128, $\mathrm{P}<0.01)$, total $\mathrm{Zn}(\mathrm{R}=-0.601 ; \mathrm{P}<0.01)$, particles 0.02-50 $\mu \mathrm{m}(\mathrm{R}=-0.579 ; \mathrm{P}<0.01)$, total $\mathrm{Cu}(\mathrm{R}=-$ 0.578; $\mathrm{P}<0.01)$, total $\mathrm{Cd}(\mathrm{R}=-0.571 ; \mathrm{P}<0.01)$, total $\mathrm{Pb}(\mathrm{R}=-0.556, \mathrm{P}<0.01)$, bioavailable $\mathrm{Zn}(\mathrm{R}=-0.519$; $\mathrm{P}<0.01)$, soluble As $(\mathrm{R}=-0.505, \mathrm{P}<0.01)$, bioavailable As $(\mathrm{R}=-0.475 ; \mathrm{P}<0.05)$ and total $\mathrm{Ni}(\mathrm{R}=-0.435, \mathrm{P}<$ $0.05)$.

The negative correlation suggests that the water content, fine and medium particle sizes and the presence of metals, especially in its bioavailable and soluble fractions, is followed by low values of electrical resistivity $[61,67,68]$.

Resistivity was also positive and significantly correlated with particles 50-2000 $\mu \mathrm{m}(\mathrm{R}=0.802$; $\mathrm{P}<0.01)$, bioavailable $\mathrm{Fe}(\mathrm{R}=0.572, \mathrm{P}<0.01)$, bioavailable $\mathrm{Pb}(\mathrm{R}=0.543 ; \mathrm{P}<0.05)$, and soluble $\mathrm{Fe}(\mathrm{R}=$ $0.512, \mathrm{P}<0.05)$, meaning that coarse grain sizes promote high resistivity values $[14,43,63]$.

Physicochemical parameters strongly correlated with resistivity $(R> \pm 0.5)$ were selected for fitting in a non-linear regression. As a result, multiple equations were obtained for the different dependent variables (Figure 5) such as polynomial-cubic for moisture $(\mathrm{Z}=0.34 ; \mathrm{P}<0.0001)$, total $\mathrm{Zn}$ $(Z=0.664 ; P<0.0001)$ and particles 50-2000 $\mu \mathrm{m}(Z=0.68 ; P<0.0001)$; polynomial-inverse of 3rd order for electrical conductivity soluble $\mathrm{Cd}(\mathrm{Z}=0.013 ; \mathrm{P}<0.0001),(\mathrm{Z}=0.018 ; \mathrm{P}<0.0001)$, bioavailable Ni $(\mathrm{Z}=0.033$; $\mathrm{P}<0.0001)$, bioavailable $\mathrm{Cd}(\mathrm{Z}=0.196 ; \mathrm{P}<0.0001)$, soluble $\mathrm{Pb}(\mathrm{Z}=0.595 ; \mathrm{P}<0.0001)$ and; exponential decay-linear combination for total $\mathrm{Cd}(\mathrm{Z}=0.10 ; \mathrm{P}<0.0001)$, particles 0.02-50 $\mu \mathrm{m}(\mathrm{Z}=0.23 ; \mathrm{P}<0.0001)$, total $\mathrm{Pb}(\mathrm{Z}=0.34 ; \mathrm{P}<0.0001)$, total $\mathrm{Cu}(\mathrm{Z}=0.39 ; \mathrm{P}<0.0001)$, and bioavailable $\mathrm{Fe}(\mathrm{Z}=0.56 ; \mathrm{P}<0.0001)$ or polynomial-quadratic for particles $<0.02 \mu \mathrm{m}(\mathrm{Z}=0.013$; $\mathrm{P}<0.0001)$.

Only $\mathrm{TN}$, total $\mathrm{Fe}$, bioavailable $\mathrm{Zn}$ and $\mathrm{Pb}$ and soluble $\mathrm{Fe}$ and $\mathrm{As}$ did not achieve all assumptions for model acceptance (residuals normality and homoscedasticity $(Z)$, and $R^{2} \geq 0.6$ ) (Figure 5).

The efficiency of each obtained model was validated by applying the corresponding model to each parameter for a validation set. This validation is shown in the Figure S1 by plotting the real value of the studied parameter measured in the field and the value estimated with the model validation samples $(\mathrm{n}=9)$.

Best fitting of estimated data was obtained for EC and bioavailable Cd with the $89 \%$ of the estimated data within the confidence interval (CI) at $95 \%$. The $78 \%$ of the estimated data for particles 0.02-50 $\mu \mathrm{m}$ and 50-2000 $\mu \mathrm{m}$, total $\mathrm{Zn}$, total $\mathrm{Cd}$ and bioavailable Ni and Fe were within $\mathrm{CI}$, verifying the good quality of the models obtained for these parameters. However, the efficiency of the models obtained for soluble $\mathrm{Cd}$, total $\mathrm{Pb}$, Total $\mathrm{Cu}$, particles $<0.02 \mu \mathrm{m}$ and soluble $\mathrm{Pb}$ was constrained because only the $67 \%, 56 \%, 33 \%, 22 \%$ and $1 \%$ respectively of the estimated data were located within the CI.

This methodology was similar to that used by other authors $[31,33,35]$ who also faced estimated and real moisture data in plots as well as metals [19]. 
13 of 20
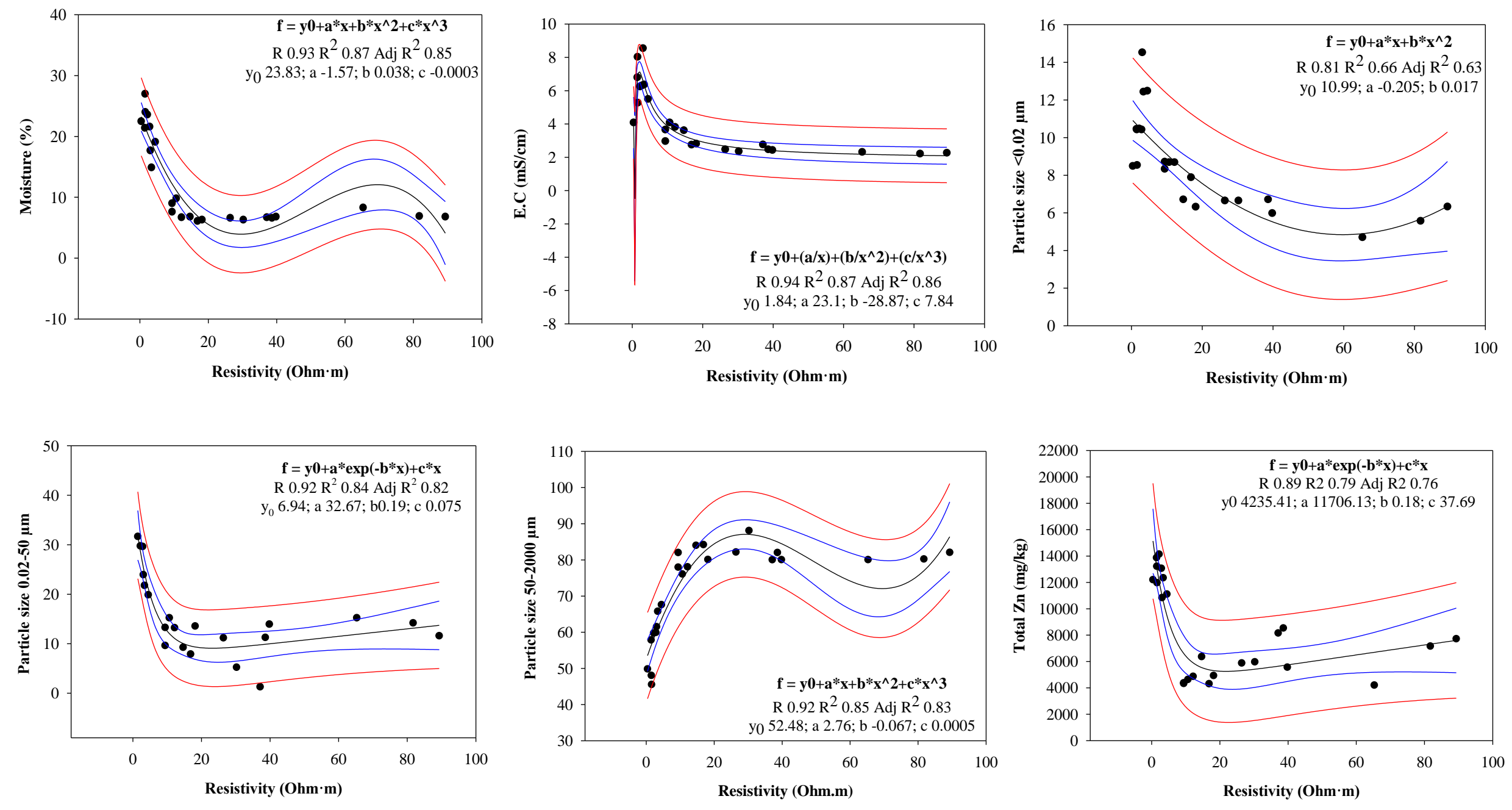

\footnotetext{
95\% Confidence Band $-95 \%$ Prediction Band

95\% Confidence Band $-95 \%$ Prediction Band
} 
14 of 20
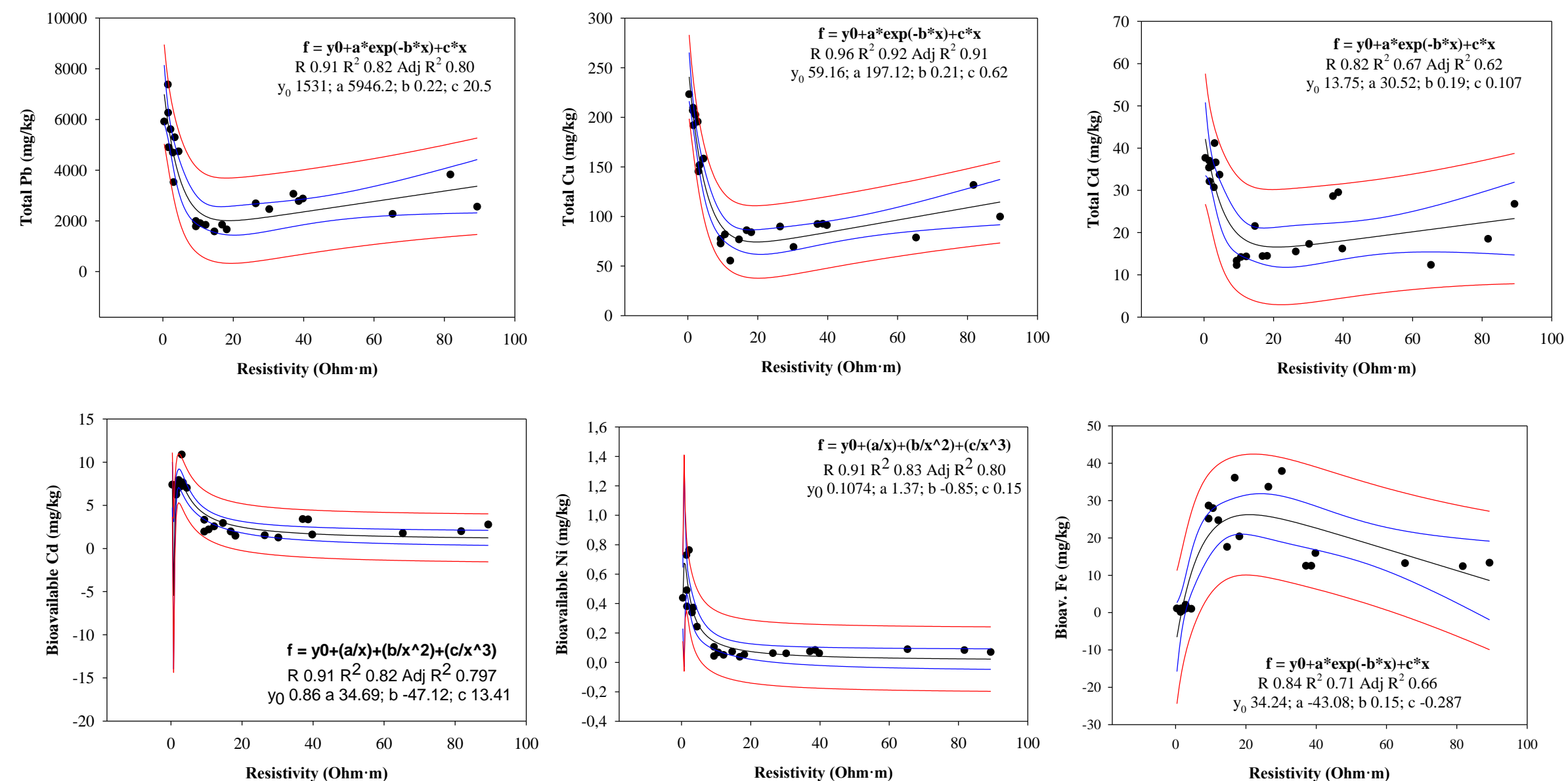

95\% Confidence Band

95\% Prediction Band

Predion Band 


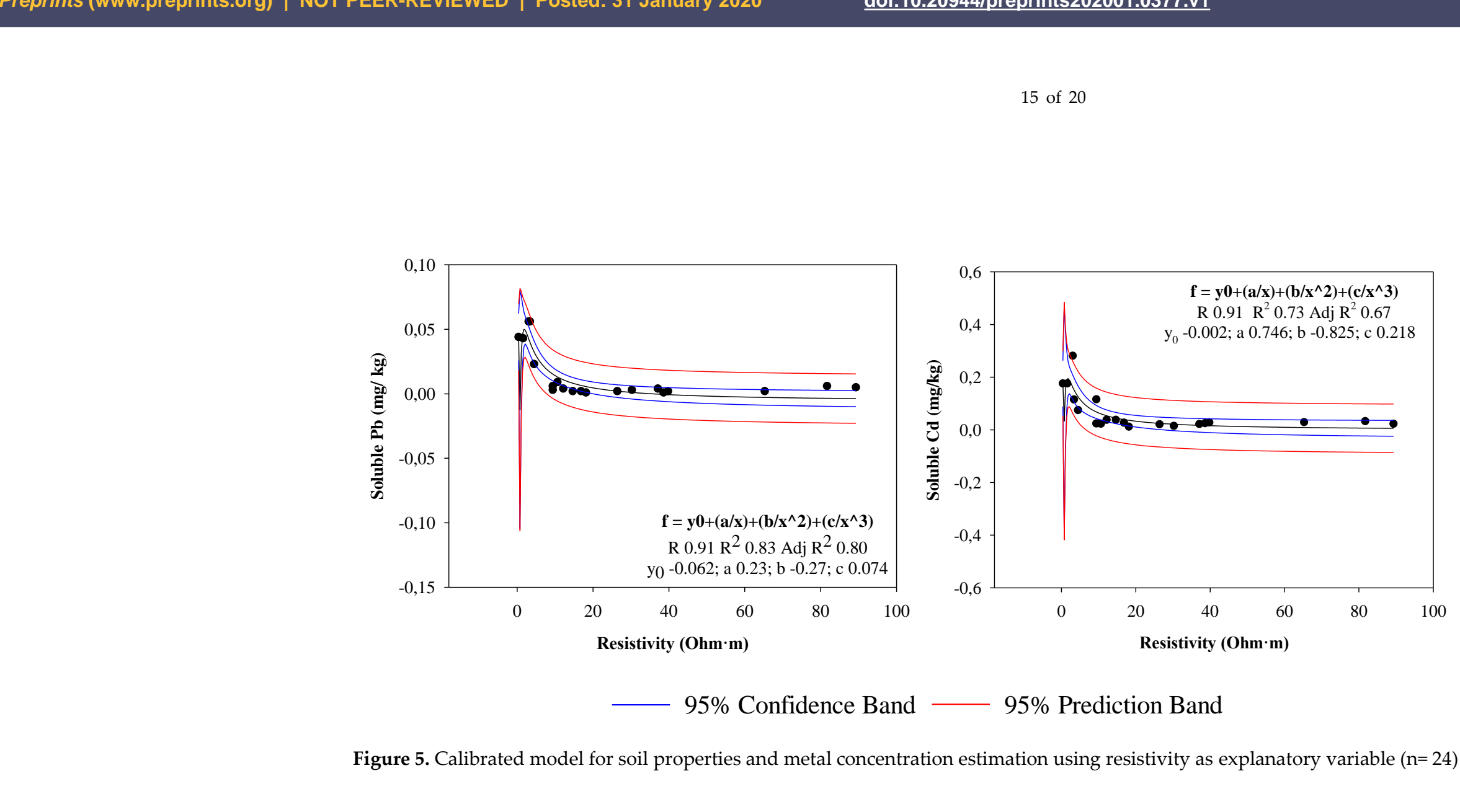
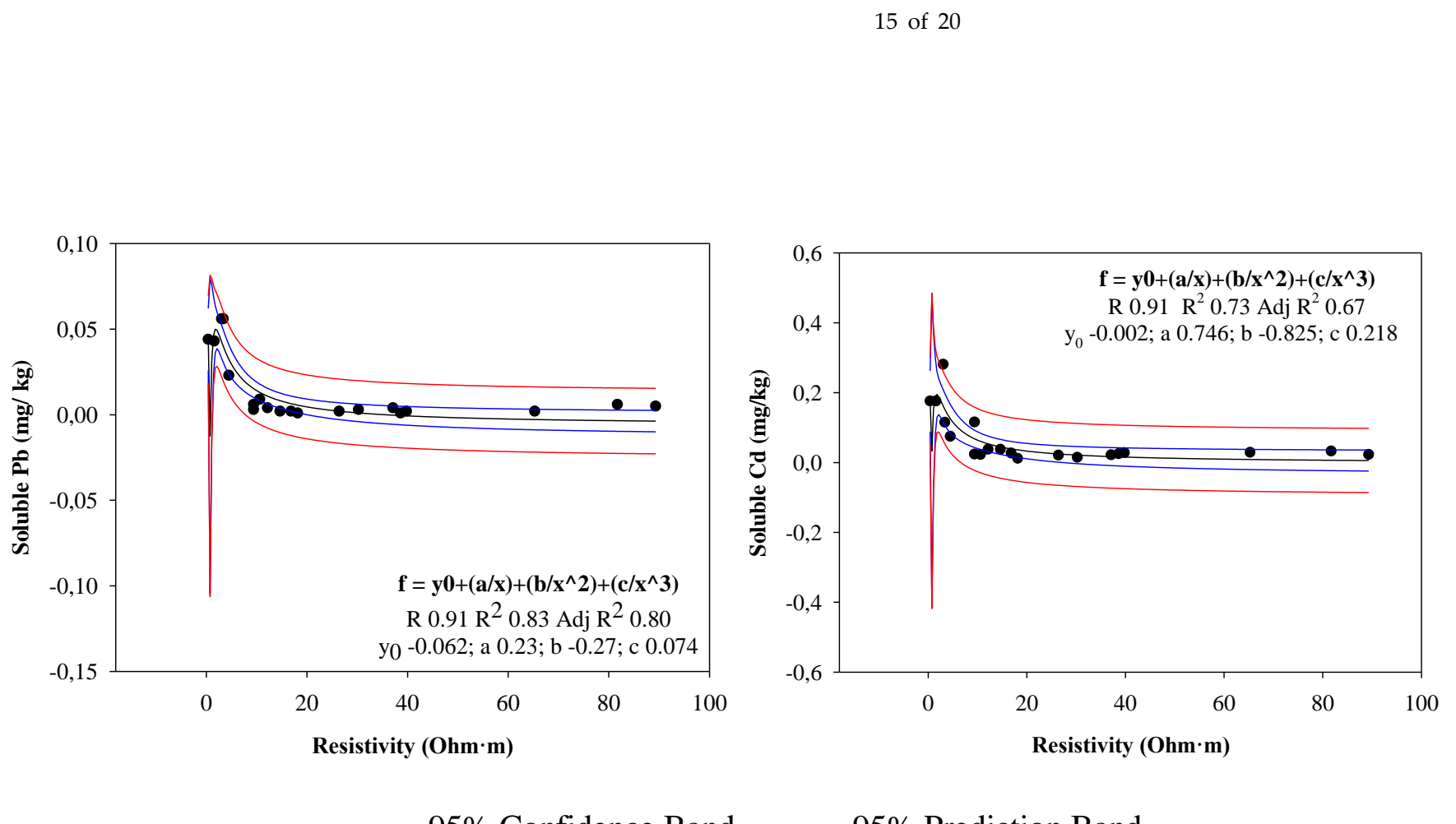

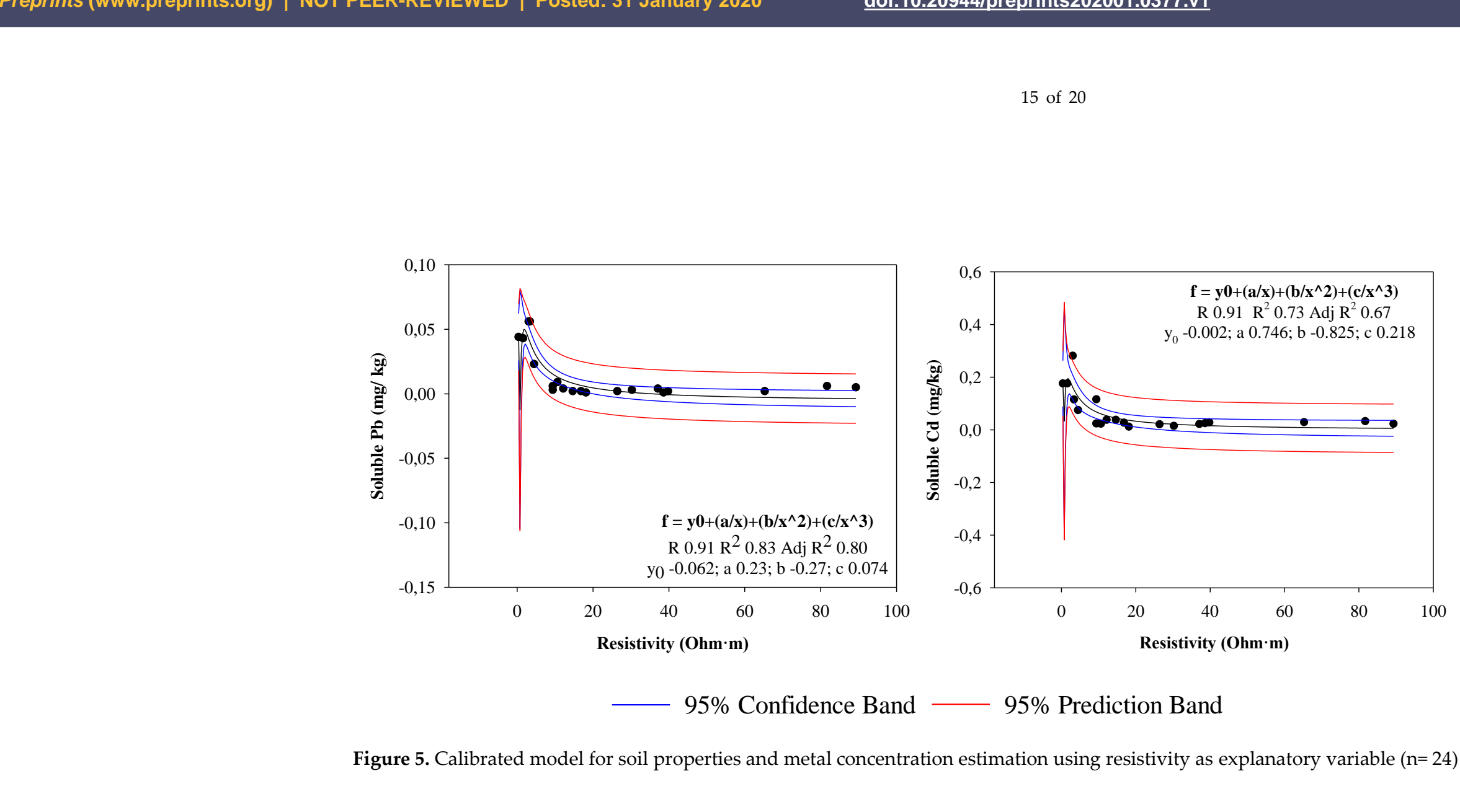

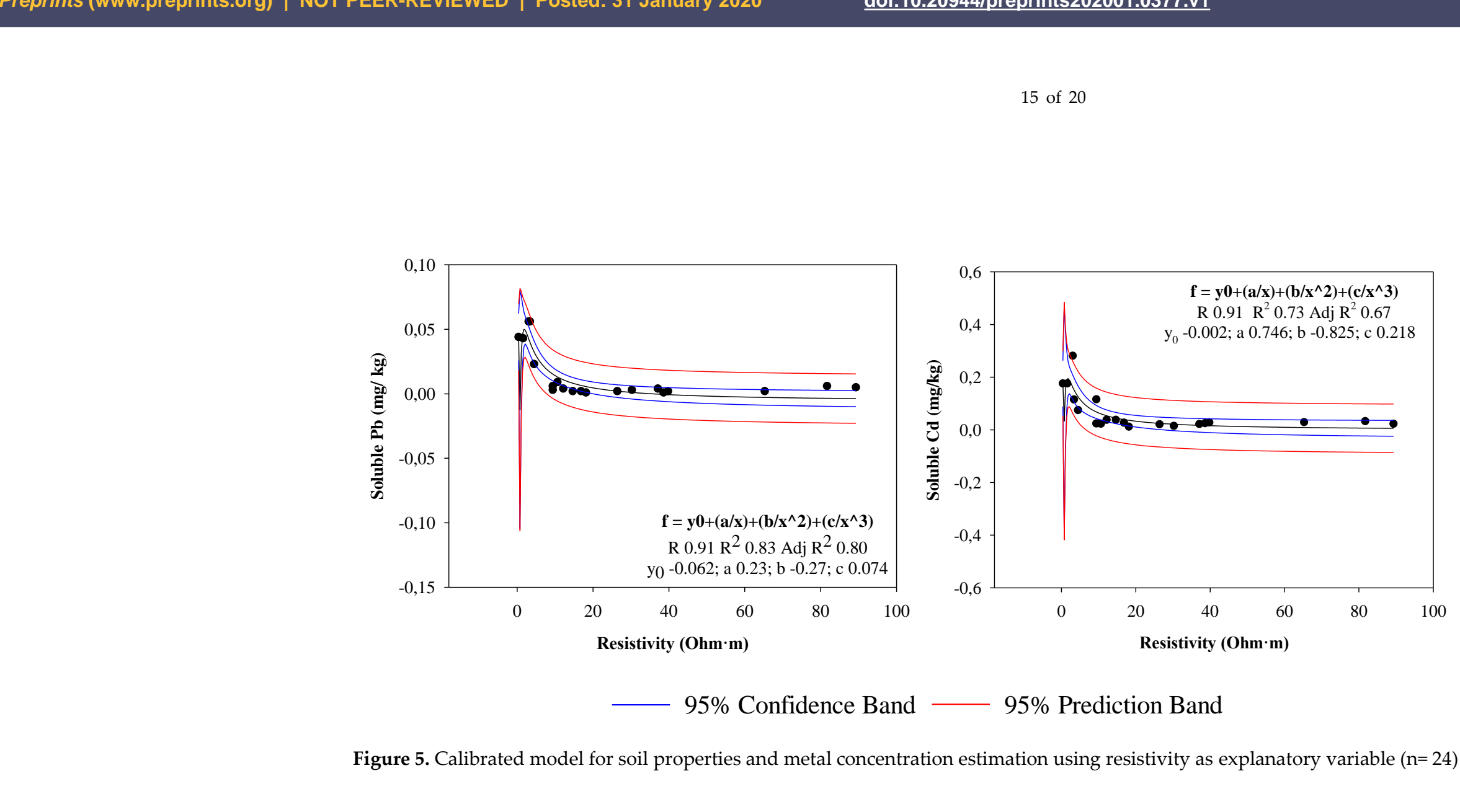

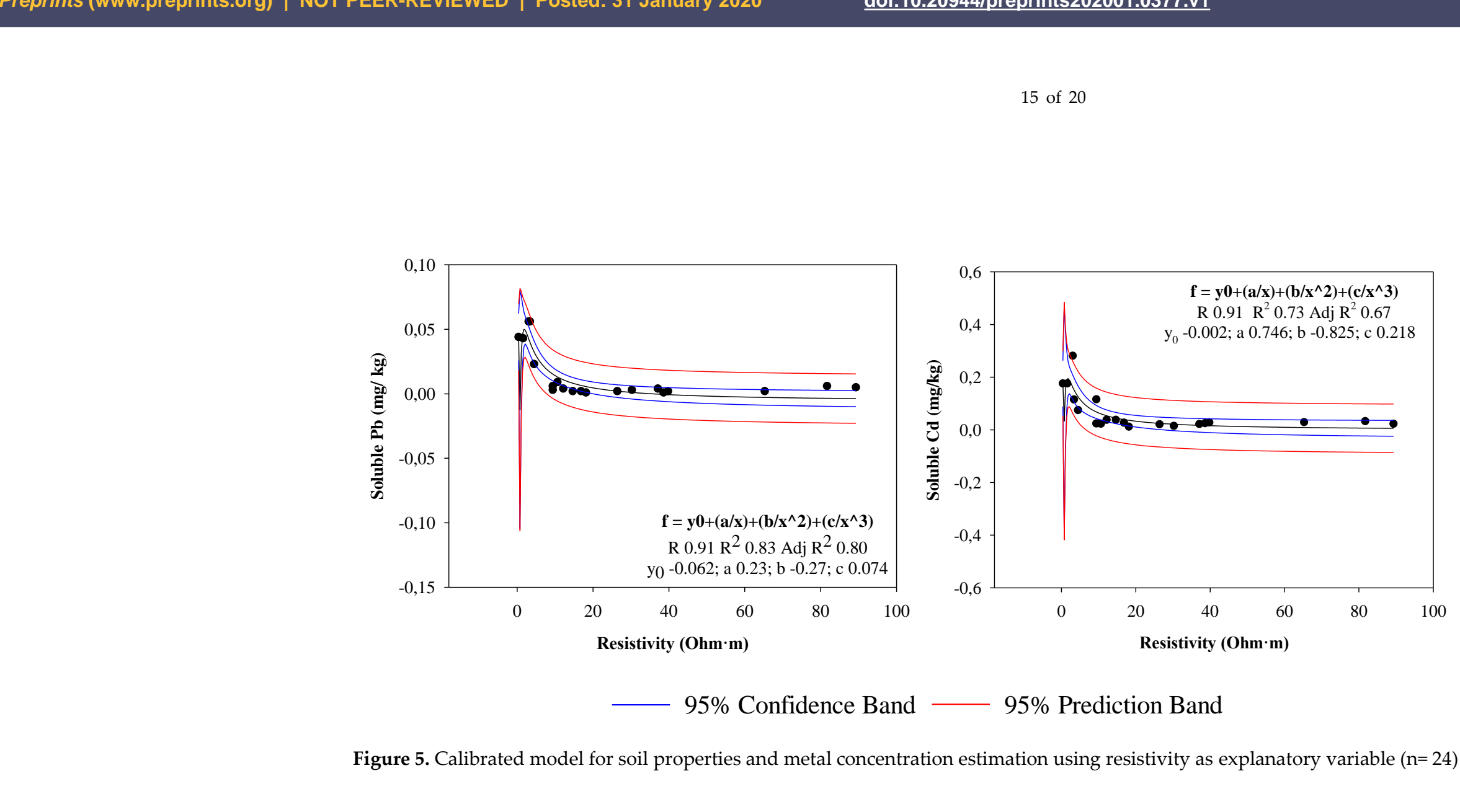

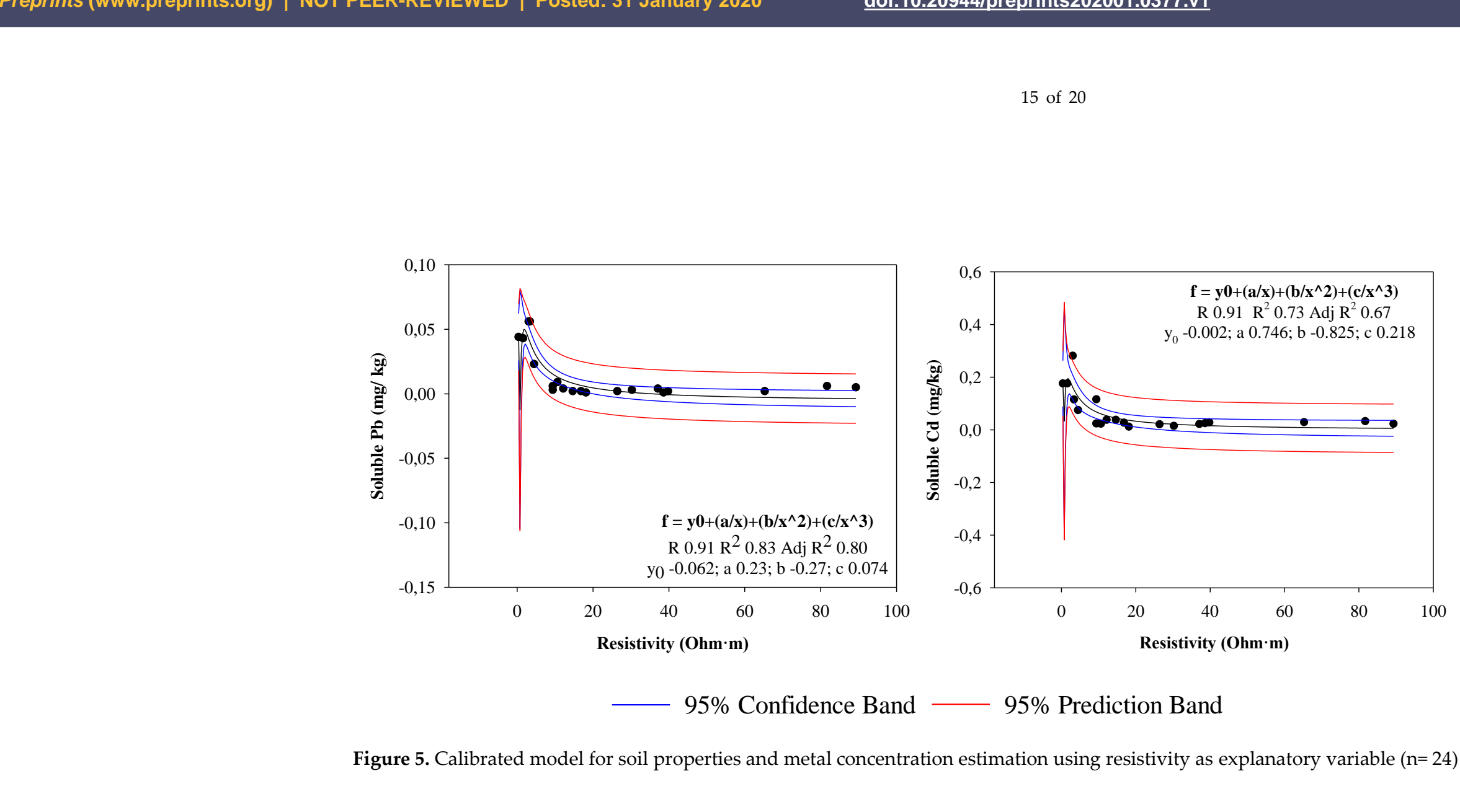

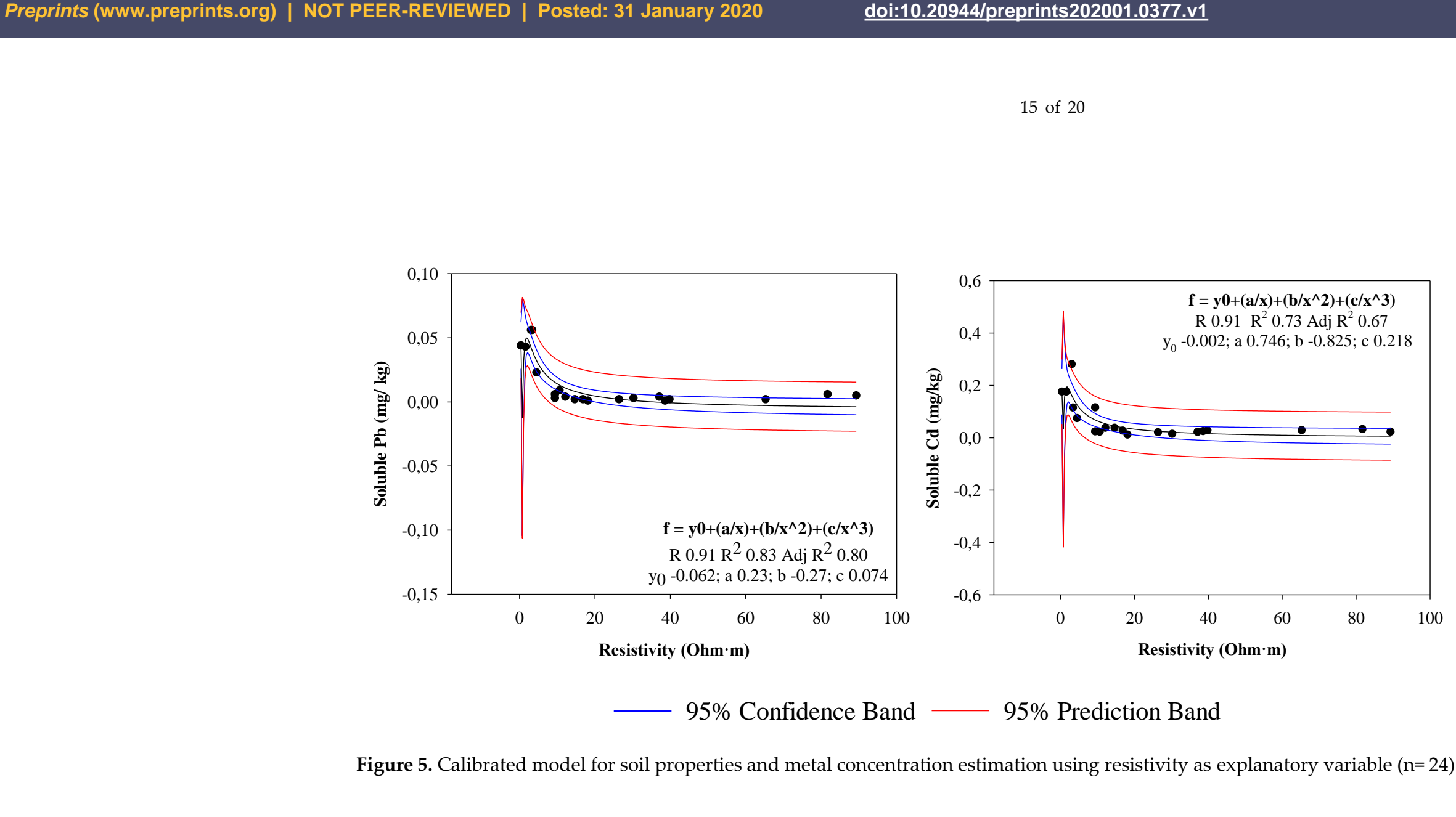

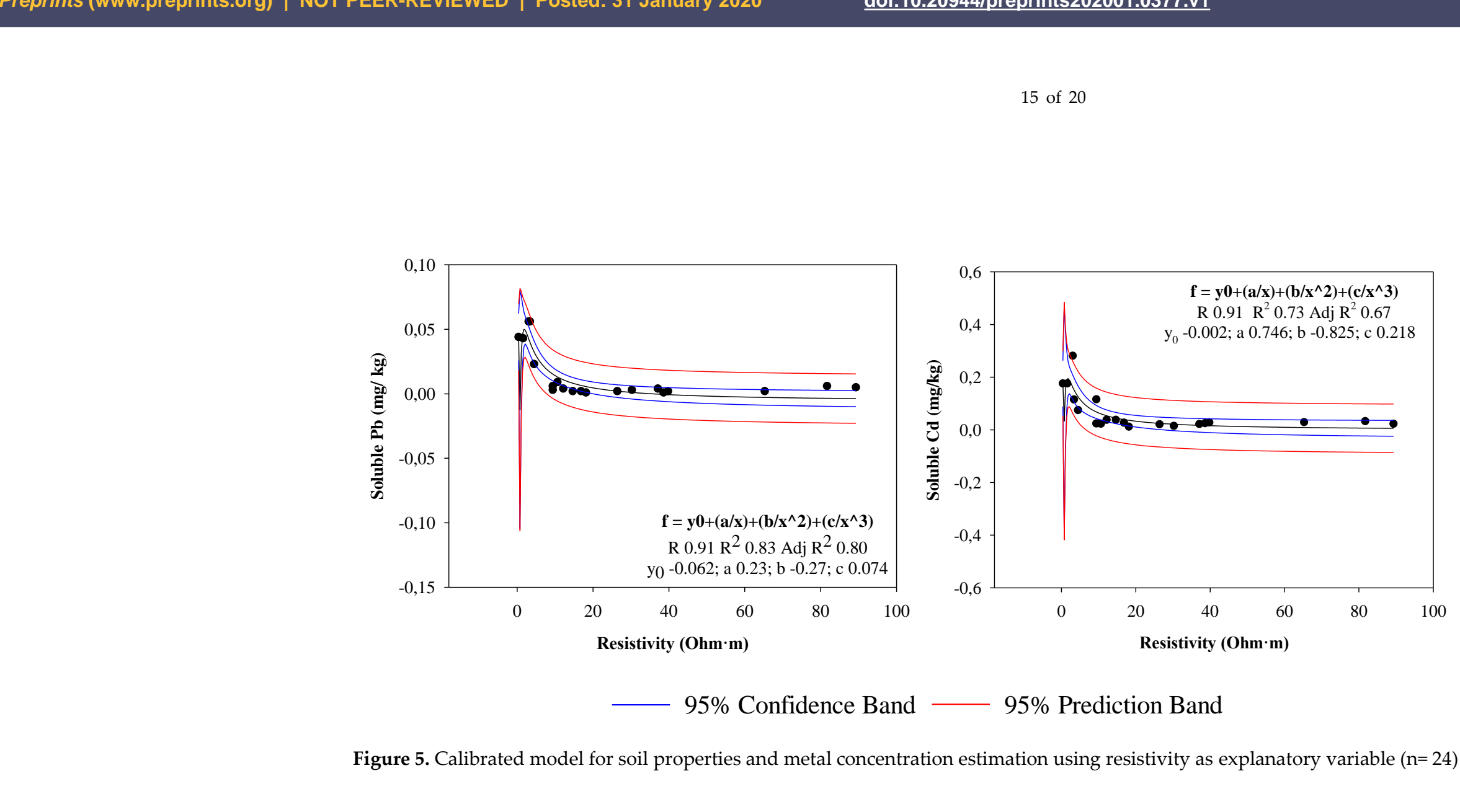

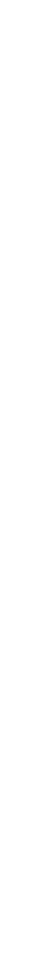

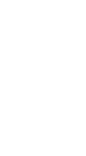

.




\section{Conclusions}

The ERT method has been proved as a useful tool for supporting geochemical surveys in order to identify subareas with different materials within tailings ponds and establish relationships among the resistivity and the wastes properties and metal concentrations. On this way, a high resistivity region was depicted in the surface of G2 and G3 as well the G1 materials was catalogued as nonresistive. The relationships among the fine particle size distribution, higher metal concentration and solubility of the materials infilling the pond with low values of electrical resistivity has also been proved.

About the metal concentration in the tailings pond it decreased as $\mathrm{Zn}>\mathrm{Pb}>\mathrm{As}>\mathrm{Cu}>\mathrm{Cd}>\mathrm{Ni}>\mathrm{Cr}$ being the $\mathrm{Cd}$ the most available and water-soluble metal in the pond, especially in the G1 area.

The ERT technique could be also useful in estimating some of the waste properties and metal concentrations in tailings ponds with similar geochemical characteristics by calibration of empirical non-linear regression models. Thus, it is believed that the calibrated models obtained for EC, bioavailable $\mathrm{Cd}$, particles $0.02-50 \mu \mathrm{m}$ and 50-2000 $\mu \mathrm{m}$, total $\mathrm{Zn}$, total $\mathrm{Cd}$ and bioavailable $\mathrm{Ni}$ and $\mathrm{Fe}$ could be used to estimate these parameters in tailings ponds of Cartagena-La Unión mining district and other Mediterranean semiarid mining areas with similar materials composition. Hence, this procedure could avoid hard and expensive field surveys by reducing the number of boreholes and soil samples.

Supplementary Materials: The following are available online, Figure S1. Relationship between the real parameter and the calculated parameter using the calibrated model obtained for each soil property and metal

Acknowledgments: In memory of Joselito M. Arocena, University of Prince George, Canada. Thanks for your support wherever you are.

\section{References}

1. Thornton, I. Impacts of mining on the environment; some local, regional and global issues. Applied Geochemistry 1996, 11, 355-361

2. Martín-Crespo, T.; Gómez-Ortiz, D.; Martín-Velázquez, S.; Esbrí, J.M.; De Ignacio-San José, C.; SánchezGarcía, M.J.; Montoya-Montes, I.; Martín-González, F. Abandoned mine tailings in cultural itineraries: Don Quixote Route (Spain). Engineering Geology 2015, 197, 82-93

3. Gómez-Ortiz, D.; Martín-Velázquez, S.; Martín-Crespo, T.; De Ignacio-San José, C.; Lillo, J. Application of electrical resistivity tomography to the environmental characterization of abandoned massive sulphide mine ponds (Iberian Pyrite Belt, SW Spain). Near Surface Geophysics 2010, 8, 65-74.

4. Kabas, S.; Faz, A.; Acosta, J.A.; Zornoza, R.; Martínez-Martínez, S.; Carmona, D.M.; Bech, J. Effect of marble waste and pig slurry on the growth of native vegetation and heavy metal mobility in a mine tailing pond. Journal of Geochemical Exploration 2012, 123, 69-76.

5. Zornoza, R.; Faz, A.; Carmona, D.M.; Martínez-Martínez, S.; Acosta, J.A. Plant Cover and Soil Biochemical Properties in a Mine Tailing Pond Five Years After Application of Marble Wastes and Organic Amendments. Pedosphere 2012, 22, 22-32.

6. Martinez-Pagan, P.; Cano, A.F.; Aracil, E.; Arocena, J.M. Electrical Resistivity Imaging Revealed the Spatial Properties of Mine Tailing Ponds in the Sierra Minera of Southeast Spain. Journal of Environmental and Engineering Geophysics 2009, 14, 63-76. 
7. Cortada, U.; Martínez, J.; Rey, J.; Hidalgo, M.C.; Sandoval, S. Assessment of tailings pond seals using geophysical and hydrochemical techniques. Engineering Geology 2017, 223, 59-70.

8. Conesa, H.M., Faz, A., Arnaldos, R. Initial studies for the phytostabilization of a mine tailing from the Cartagena-La Union Mining District (SE Spain). Chemosphere, 2007, 66, 38-44.

9. Parra, A., Faz, A., Zornoza, R., Conesa, E., \& Gómez-López, M.D. Heavy metal accumulation and tolerance in spontaneous vegetation in El Avenque dry river bed, southeast of Spain. In Proceedings Tailings and Mine Waste Vancouver, British Columbia, Canada: University of British Columbia, 2012, pp. 445-450.

10. Norland, M.R., Veith, D.L. Revegetation of coarse taconite iron ore tailing using municipal solid waste compost. Selected papers presented at the Conference on Hazardous Waste Remediation, 1995, 41, 123-134.

11. Acosta, J.A., Martínez-Pagán, P., Martínez-Martínez, S., Faz, A., Zornoza, R., Carmona, D.M. Assessment of environmental risk of reclaimed mining ponds using geophysics and geochemical techniques. Journal of Geochemical Exploration, 2014, 147, 80-90.

12. Martín-Crespo, T., Gómez-Ortiz, D., Martín-Velázquez, S., Martínez-Pagán, P., De Ignacio, C., Lillo, J., Faz, A. Geoenvironmental characterization of unstable abandoned mine tailings combining geophysical and geochemical methods (Cartagena-La Union district, Spain). Engineering Geology, 2018, 232, 135-146

13. Loke, M.H., Chambers, J.E., Rucker, D.F., Kuras, O., Wilkinson, P.B. Recent developments in the directcurrent geoelectrical imaging method. Journal of Applied Geophysics, 2013, 95, 135-156.

14. Reynolds, J.M. An Introduction to applied and environmental geophysics. Oxford, Wiley-blackwell (ed).Chichester, UK, 2011.

15. Rucker, D.F., Loke, M.H., Levitt, M.T., Noonan, G.E.Electrical-resistivity characterization of an industrial site using long electrodes. Geophysics, 2010, 75, 95-104.

16. Rosales R.M., Martinez-Pagan P, Faz A., Monero-Cornejo J. Environmental monitoring using electrical resistivity tomography (ERT) in the subsoil of three former petrol stations in SE of Spain. Water air soil pollut, 2012, 223, 3757-3773.

17. Rosales, R.M, Martínez-Pagán, P., Faz, A., Bech, J. Study of subsoil in former petrol stations in SE of Spain: Physicochemical characterization and hydrocarbon contamination assessment. Journal of Geochemical Exploration, 2014, 147, 306-320.

18. Martin-Crespo, T., Gomez-Ortiz, D., Martinez-Pagan, P., De Ignacio-San Jose, C., Martin-Velazquez, S., Lillo, J., Faz, A. Geoenvironmental characterization of riverbeds affected by mine tailings in the Mazarron district (Spain). Journal of Geochemical Exploration, 2012, 119-120, 6-16.

19. Vásconez-Maza, M.D., Martínez-Segura, M.A., Bueso, M.C., Faz, Á, García-Nieto, M. C., Gabarrón, M., Acosta, J. A. Predicting spatial distribution of heavy metals in an abandoned phosphogypsum pond combining geochemistry, electrical resistivity tomography and statistical methods. Journal of Hazardous Materials, 2019, 374, 392-400.

20. Page, L.M. Use of the Electrical Resistivity Method for Investigating Geologic and Hydrologic Conditions in Santa Clara County, California. Groundwater, 1968, 6, 31-40.

21. Wilson, S.R., Ingham, M., McConchie, J.A. The applicability of earth resistivity methods for saline interface definition. Journal of Hydrology, 2006, 316, 301-312.

22. Griffiths, D.H., Barker, R.D. Electrical imaging in archaeology. Journal of Archaeological Science, 1994, 21, 153158.

23. Simyrdanis, K., Papadopoulos, N., Kim, J-H., Tsourlos, P., Moffat, I. Archaeological investigations in the shallow seawater environment with electrical resistivity tomography. Near Surface Geophysics, 2015, 13, 601611. 
24. White, R.M.S., Collins, S., Denne, R., Hee, R., \& Brown, P. A new survey design for 3D IP inversion modelling at Copper Hill. Exploration Geophysics, 2001, 32, 152-155.

25. Bauman, P. 2-D resistivity surveying for hydrocarbons - A primer. CSEG Recorder, 2005, 30, $25-33$.

26. Legault, J.M., Carriere, D., Petrie, L. Synthetic model testing and distributed acquisition dc resistivity results over an unconformity uranium target from the Athabasca Basin, northern Saskatchewan. The Leading Edge , 2008, 27, 46-51.

27. Linderholm, P., Marescot, L., Loke, M.H., Renaud, P. Cell culture imaging using microimpedance tomography. IEEE Transactions on Biomedical Engineering, 2008, 55, 138-146.

28. Storz H., Storz W., Jacobs, F. Electrical resistivity tomography to investigate geological structures of the earth's upper crust. Geophysical prospecting, 2000, 48,455-471.

29. Martínez-Pagán, P., Faz, A., Acosta, J.A., Carmona, D.M., \& Martínez-Martínez, S. A multidisciplinary study for mining landscape reclamation: A study case on two tailing ponds in the Region of Murcia (SE Spain). Physics and Chemistry of the Earth, 2011, 36, 1331-1344.

30. Lghoul, M., Teixido T., Peña , J.A., Hakkou, R., Kchikach, A., Guerin, R., Jaffal, M., Zouhri, L. Electrical and Seismic Tomography Used to Image the Structure of a Tailings Pond at the Abandoned Kettara Mine, Morocco. Mine Water Environ,2012, 31, 53-61.

31. Michot, D., Benderitter, Y., Dorigny, A., Nicoullaud, B., King, D., Tabbagh, A. Spatial and temporal monitoring of soil water content with an irrigated corn crop cover using surface electrical resistivity tomography. Water Resour Res, 2003, 39 (5), 1138.

32. Brevik, E.C., Fenton, T.E., Lazari, A. Soil electrical conductivity as a function of soil water content and implications for soil mapping. Precis. Agric., 2006, 7, 393-404.

33. Brunet, P., Clément, R., Bouvier, C. Monitoring soil water content and deficit using Electrical Resistivity Tomography (ERT) - A case study in the Cevennes area, France. J. Hydrol, 2010, 380,146-153.

34. Kotková, K., Nováková, T., Tůmová, S., Kiss, T., Popelka, J., Faměra, M. Migration of risk elements within the floodplain of the Litavka River, the Czech Republic. Geomorphology, 2019, 329, 46-57.

35. Hadzick, Z.Z., Guber, A.K., Pachepsky, Y.A., Hill, R.L. Pedotransfer functions in soil electrical resistivity estimation. Geoderma, 2011, 164, 195-202.

36. AEMET. 2019. Available online http://www.aemet.es/es/serviciosclimaticos/datosclimatologicos/valoresclimatologicos?1=7031\&k=mur

37. Acosta, J.A., Abbaspour, A., Martínez, G.R., Martínez-Martínez, S., Zornoza, R., Gabarrón, M., Faz, A. Phytoremediation of mine tailings with Atriplex halimus and organic/inorganic amendments: A five-year field case study. Chemosphere, 2018, 204, 71-78.

38. Australian National Committee on Large Dams (ANCOLD). Guidelines on tailings dam design, construction and operation, 1999. Available in: http://www.ancold.org.au

39. Butler, D. K. Near-Surface Geophysics. Society of Exploration Geophysicists, Tulsa, Oklahoma, U.S.A., 2005, p.758.

40. Dahlin, T, Zhou, B. A numerical comparison of 2D resistivity imaging with 10 electrode arrays. Geophysical Prospecting, 2004, 52, 379-398.

41. Martorana, R., Capizzi, P., D’Alessandro, A., \& Luzio, D. Comparison of different sets of array configurations for multichannel 2D ERT acquisition. Journal of Applied Geophysics, 2017, 137, 34-48.

42. Bernard J. Short note on the depth of investigation of electrical methods: IRIS Instruments, 2003, Orleans, France, 8 pp. Available in: http://www.iris-instruments.com

43. Loke, M. H. Tutorial: 2-D and 3-D electrical imaging surveys. Geotomosoft, 2015. Available in: 
http://www.geotomosoft.com

44. Loke, M.H., Barker, R.D. Rapid least-squares inversion of apparent resistivity pseudosections by a quasiNewton method. Geophysical Prospecting, 1996, 44(1), 131-152.

45. Martínez Pagán, P. Aplicación de diferentes técnicas no destructivas de prospección geofísica a problemas relacionados con contaminación ambiental producida por diferentes actividades antrópicas en la Región de Murcia [Application of different non-invasive geophysical prospecting methods to problems related to environmental contamination caused by anthropical activities in the Region of Murcia (Spain)] (Doctoral thesis). 2006. Retrieved from ProQuest Dissertations and Theses database. (UMI No. 3392396)

46. Styles, P. Environmental Geophysics. Everything you ever wanted (needed!) to know but were afraid to ask! (Vol. 7). Houten, The Netherlands: European Association of Geoscientists and Engineers, 2012. Available in https://bookshop.eage.org/book-author/peter-styles/

47. Soil Survey Staff. Soil survey laboratory methods manual. Version no. 4.0. USDA NRCS. Soil Survey Investigations Report No. 42. U.S. Govt. Print. Office, Washington D.C., 2004.

48. Dewis, J., Freitas, F. Physical and chemical methods of soil and water analyses. Soils Bulletin (FAO) №10. FAO, Roma, 1970.

49. Risser, J.A., Baker, D.E. Testing soils for toxic metals. In: R. L. Westerman (Ed). Soil Testing and plant analysis. Soil Science Society of America. Special Publication 3.3rd Ed., Madison, 1990, pp 275-298.

50. Lindsay W.L., Norvell W.A. Development of a DTPA soil test for Zn, Fe, Mn, and Cu. Soil Science Society of America Journal, 1978, 42, 421-428.

51. Crock, J.G., Severson, R.C.. Four reference soil and rock samples for measuring element availability in the western energy regions: U.S. Geological Survey Circular, 1980,841, 16 p.

52. Buurman P., van Lagen, B., Veltorst, E.J. Manual for Soil and Water Analysis. Backhuys publishers, Technical report, Leiden, Netherlands, 1996.

53. Frau, F. The formation-dissolution-precipitation cycle of melanterite at the abandoned pyrite mine of Genna Luas in Sardinia, Italy: environmental implications. Mineralogical Magazine, 2000, 64 (6), 995-1006.

54. Zornoza, R., Faz, A., Martínez-Martínez, S., Acosta, J.A., Constantini, R., Gabarrón, M., Gómez-López, M.D. Suitability of Different Mediterranean Plants for Phytoremediation of Mine Soils Affected with Cadmium. Springer International Publishing Switzerland 2016. A.A. Ansari et al. (eds.), Phytoremediation, 2016.

55. Martínez-Sánchez, M.J., Pérez-Sirvent, C. Niveles de fondo y niveles genéricos de referencia de metales pesados en suelos de la Región de Murcia. Secretaria autonómica para la sostenibilidad. Dirección General de Calidad Ambiental y Universidad de Murcia (Ed), 2007.

56. WHO (World Health Organization), Ten chemicals of major public health concern in International Programme on Chemical Safety, $2019 . \quad$ Available in https://www.who.int/ipcs/assessment/public_health/chemicals_phc/en/

57. Perez-Sirvent, C., Hernandez-Perez, C., Martinez-Sanchez, M.J., Garcia-Lorenzo, M.L., Bech, J. Geochemical characterisation of surface waters, topsoils and efflorescences in a historic metal-mining area in Spain. J Soils Sediments, 2016, 16, 1238-1252.

58. Gabarron, M, Faz, A., Acosta, J.A. Use of multivariable and redundancy analysis to assess the behavior of metals and arsenic in urban soil and road dust affected by metallic mining as a base for risk assessment. Journal of Environmental Management, 2018, 206, 192-201.

59. Paillet Y., Cassagne N., Brun J.J. 2010. Monitoring forest soil properties with electrical resistivity. Biol Fertil Soils, 2010, 46, 451-460. 
60. Maloteau, S., Blanchy, G., Javaux, M, Garré, S. Influence of plant roots on electrical resistivity measurements of cultivated soil columns. Geophysical Research Abstracts. Vol. 18, EGU2016-11695, 2016. EGU General Assembly 2016

61. Acosta, J.A., Faz, A., Martínez, P., Martínez-Martínez, S., Muñoz, M.A., Zornoza, R., Bech, Environmental Risk Assessment of Tailings Ponds Using Geophysical and Geochemical Techniques. Assessment. In Restoration and Reclamation of Mining Influenced Soils, 2017 Elsevier Inc., pp 135-148.

62. Samouëlian, A., Cousin, I., Tabbagh,A., Bruand, A., Richard, G. Electrical resistivity survey in soil science: a review. Soil ETillage Research, 2005, 83, 173-193.

63. Majoribanks, R. Geological Methods in Mineral Exploration and Mining. Springer, 2010, 2nd Ed.

64. Faz, A., Acosta, J.A., Martínez-Martínez, S., Martínez-Pagán, P., Carmona, D.M., Zornoza, R., Kabas, S. Risk assessment for the environment, population and infrastructures of some abandoned tailing ponds in the mining district of Cartagena-La Union (SE Spain). In Metal Contamination: Sources, Detection and Environmental Impact, 2013, pp.194-217.

65. Yurkevich, N., Bortnikova, S., Olenchenko, V., Abrosimova, N., Saeva, O., Karin, Y. Study of Water-rock Interaction in Sulfide Mining Tailings using Geochemical and Geoelectrical Methods. 15th Water-Rock Interaction International Symposium, WRI-15. Procedia Earth and Planetary Science, 2017, 17112 - 115.

66. Placencia-Gómez, E., Parviainen, A., Hokkanen, T., Loukola-Ruskeeniemi, K., Integrated geophysical and geochemical study on AMD generation at the Haveri Au-Cu mine tailings, SW Finland. Environ Earth Sci, 2010, 61, 1435-1447.

67. Alamry, A.S., van der Meijdeb, M., Noomenb, M., Addinkc, E.A., van Benthemc, R., de Jong, S.M. Spatial and temporal monitoring of soil moisture using surface electrical resistivity tomography in Mediterranean soils. Catena, 2017, 157, 388-396.

68. Puttiwongrak, A., Suteerasak, T., Mai, P.K., Hashimoto, K., Gonzalez, J.C., Rattanakom, R., Prueksakorn, K. Application of multi-monitoring methods to investigate the contamination levels and dispersion of $\mathrm{Pb}$ and Zn from tin mining in coastal sediments at Saphan Hin, Phuket, Thailand. Journal of Cleaner Production,2019, $218,108-117$. 